ORNL/TM-2014/207

\title{
Updated Peach Bottom Model for MELCOR 1.8.6: Description and Comparisons
}

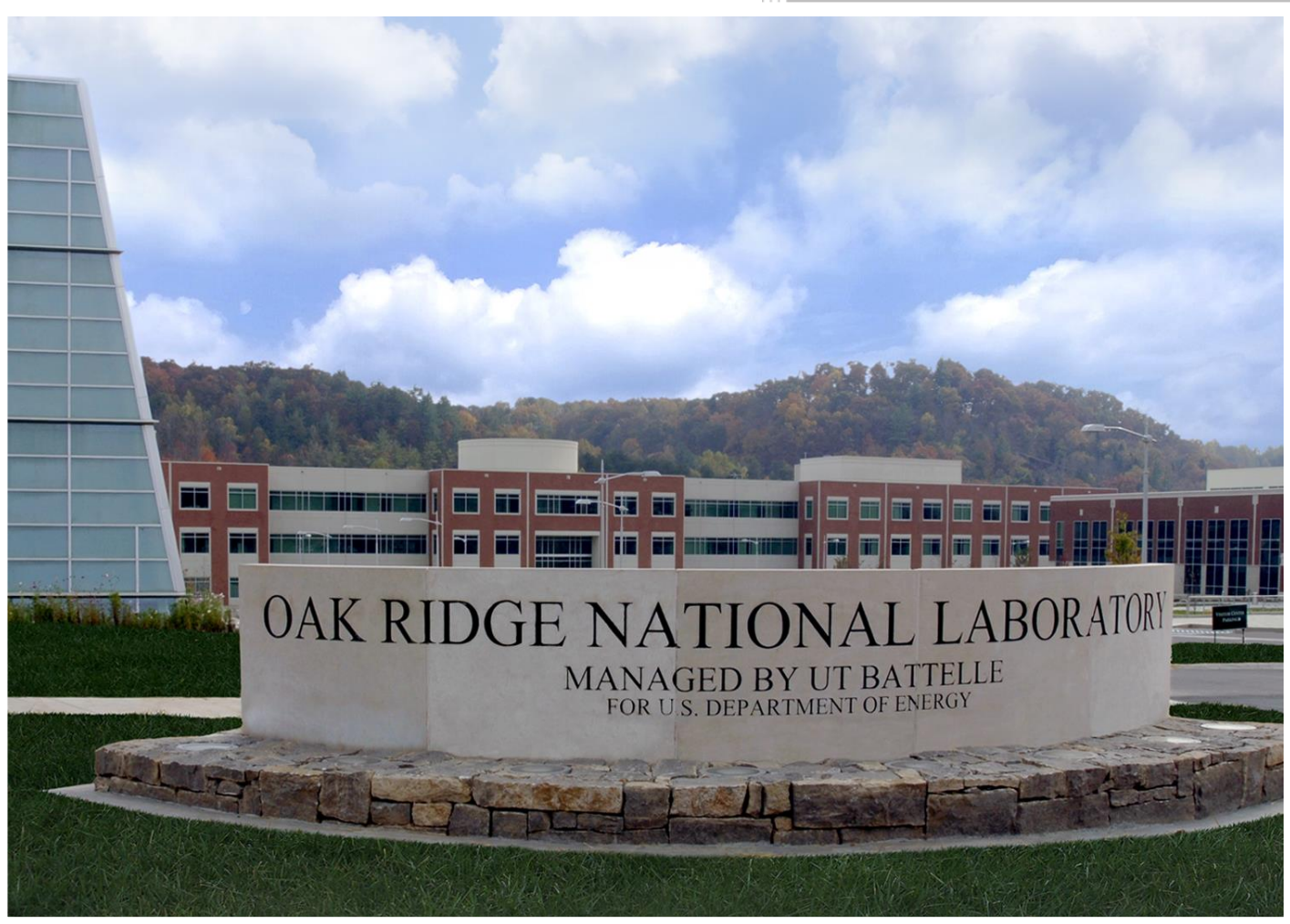

Approved for public release; distribution is unlimited.

Kevin R. Robb

August 2014 


\section{DOCUMENT AVAILABILITY}

Reports produced after January 1, 1996, are generally available free via US Department of Energy (DOE) SciTech Connect.

Website http://www.osti.gov/scitech/

Reports produced before January 1, 1996, may be purchased by members of the public from the following source:

National Technical Information Service

5285 Port Royal Road

Springfield, VA 22161

Telephone 703-605-6000 (1-800-553-6847)

TDD 703-487-4639

Fax 703-605-6900

E-mail info@ntis.gov

Website http://www.ntis.gov/help/ordermethods.aspx

Reports are available to DOE employees, DOE contractors, Energy Technology Data Exchange representatives, and International Nuclear Information System representatives from the following source:

Office of Scientific and Technical Information

PO Box 62

Oak Ridge, TN 37831

Telephone 865-576-8401

Fax 865-576-5728

E-mail reports@osti.gov

Website http://www.osti.gov/contact.html

This report was prepared as an account of work sponsored by an agency of the United States Government. Neither the United States Government nor any agency thereof, nor any of their employees, makes any warranty, express or implied, or assumes any legal liability or responsibility for the accuracy, completeness, or usefulness of any information, apparatus, product, or process disclosed, or represents that its use would not infringe privately owned rights. Reference herein to any specific commercial product, process, or service by trade name, trademark, manufacturer, or otherwise, does not necessarily constitute or imply its endorsement, recommendation, or favoring by the United States Government or any agency thereof. The views and opinions of authors expressed herein do not necessarily state or reflect those of the United States Government or any agency thereof. 
Reactor and Nuclear Systems Division

\title{
UPDATED PEACH BOTTOM MODEL FOR MELCOR 1.8.6: DESCRIPTION AND COMPARISONS
}

\author{
Kevin R. Robb
}

Date Published: August 2014

\author{
Prepared by \\ OAK RIDGE NATIONAL LABORATORY \\ Oak Ridge, Tennessee 37831-6283 \\ managed by \\ UT-BATTELLE, LLC \\ for the \\ US DEPARTMENT OF ENERGY \\ under contract DE-AC05-00OR22725
}





\section{CONTENTS}

LIST OF FIGURES
LIST OF TABLES
ACRONYMS AND ABBREVIATIONS
ACKNOWLEDGEMENTS
EXECUTIVE SUMMARY
INTRODUCTION
I.





\section{LIST OF FIGURES}

Figure $\quad$ Page

Fig. 1. Reactor water level response, MELCOR 1.8.6 vs MELCOR 1.8.5.............................................. 9

Fig. 2. Reactor pressure response, MELCOR 1.8.6 vs MELCOR 1.8.5 ............................................ 10

Fig. 3. Containment pressure response, MELCOR 1.8.6 vs MELCOR 1.8.5 ...................................... 10

Fig. 4. Hydrogen generation response, MELCOR 1.8.6 vs MELCOR 1.8.5 ......................................... 11

Fig. 5. Reactor water level response, eight vs one pool control volumes. .......................................... 12

Fig. 6. Reactor pressure response, eight vs one pool control volumes. ................................................. 13

Fig. 7. Containment pressure response, eight vs one pool control volumes. ........................................ 13

Fig. 8. Hydrogen generation response, eight vs one pool control volumes. ........................................... 14

Fig. 9. Suppression pool temperature response, eight pool control volumes.......................................... 14

Fig. 10. Suppression pool temperature response, one pool control volumes......................................... 15

Fig. 11. Reactor water level response, modified vs unmodified safety relief valve logic. ....................... 16

Fig. 12. Reactor pressure response, modified vs unmodified safety relief valve logic............................ 17

Fig. 13. Containment pressure response, modified vs unmodified safety relief valve logic. ..................... 17

Fig. 14. Hydrogen generation response, modified vs unmodified safety relief valve logic...................... 18

Fig. 15. Core melt temperature in pedestal region, modified vs unmodified safety relief valve logic. ...... 18

Fig. 16. Core melt spread area, modified vs unmodified safety relief valve logic. .................................. 19

Fig. 17. Reactor water level response, safety relief valve failure mode modeling. .................................. 21

Fig. 18. Reactor pressure response, safety relief valve failure mode modeling....................................... 22

Fig. 19. Containment pressure response, safety relief valve failure mode modeling. .............................. 22

Fig. 20. Hydrogen generation response, safety relief valve failure mode modeling.................................23

Fig. 21. Number of safety relief valve (SRV) actuations, SRV failure mode modeling........................... 23 



\section{LIST OF TABLES}

\section{Table}

Page

Table 1. Summary of additional edits made to the model during upgrade from 1.8 .5 to $1.8 .6 \ldots \ldots \ldots \ldots \ldots \ldots . . . . . . .3$

Table 2. Figures of merit for comparison for unmodified and modified LTSBO simulation results ........... 8

Table 3. Comparison of results from MELCOR Versions 1.8.5 and 1.8.6 ............................................. 9

Table 4. Suppression Pool Discretization Result Summary............................................................... 12

Table 5. Safety relief valve control logic modification result summary .............................................. 16

Table 6. Safety relief valve failure modes result summary (1) ............................................................ 20

Table 7. Safety relief valve failure modes result summary (2) ........................................................... 20

Table 8. Additional safety relief valve failure modes results................................................................. 21 



\section{ACRONYMS AND ABBREVIATIONS}

BNL Brookhaven National Laboratory

BWR boiling water reactor

$\mathrm{CF} \quad$ control function

HPCI high pressure coolant injection

LTSBO long term station blackout

ORNL Oak Ridge National Laboratory

RCIC reactor core isolation cooling

RPV reactor pressure vessel

SC suppression chamber

SNL Sandia National Laboratories

SOARCA State-of-the-Art Reactor Consequence Analyses Project

SRV safety relief valve 



\section{ACKNOWLEDGEMENTS}

The author would like to recognize the thoughtful reviews by Matthew Francis and Juan Carbajo. 



\section{EXECUTIVE SUMMARY}

A MELCOR 1.8.5 model of the Peach Bottom Unit 2 or 3 has been updated for MELCOR 1.8.6.

Primarily, this update involved modification of the lower head modeling. Three additional updates were also performed. First, a finer nodalization of the containment wet well was employed. Second, the pressure differential used by the logic controlling the safety relief valve actuation was modified. Finally, an additional stochastic failure mechanism for the safety relief valves was added. Simulation results from models with and without the modifications were compared. All the analysis was performed by comparing key figures of merit from simulations of a long-term station blackout scenario. This report describes the model changes and the results of the comparisons. 



\section{INTRODUCTION}

\subsection{MODEL BACKGROUND}

Peach Bottom (Unit 2 or 3) is a boiling water reactor series 4 (BWR/4) with a Mark I containment. Different MELCOR models of Peach Bottom have been developed over the last 25-30 years; these models include all the major components, including the reactor; containment; the reactor building; the various cooling systems (pumps, sprays, piping, tanks); and system and scenario control logic. The development history of the Peach Bottom plant model is summarized as follows. During the early development of MELCOR, a model for the Peach Bottom nuclear power plant was developed and tested by researchers at Brookhaven National Laboratory (BNL) in the late 1980s [1]. In the early 1990s, Juan Carbajo at Oak Ridge National Laboratory (ORNL) received MELCOR 1.8.0 from BNL; he expanded and updated the model to MELCOR 1.8.1 [2]. Through the 1990s, Carbajo exercised, expanded, and updated the model. The final version maintained at ORNL was MELCOR 1.8.4 [3]. This MELCOR model was then transferred to Dycoda, LLC, expanded, and updated to MELCOR 1.8.5 [4]. The model was then reviewed by R. L. Sanders at ORNL in 2003 [5]. Extra control functions (CFs), used to model additional mitigation measures for long-term station blackouts, were added by Francis and Garvey at the University of Tennessee in 2006 [6, 7].

Since the work of Francis, additional modeling improvements have been made at ORNL by Robb to the Peach Bottom model, including its upgrade to MELCOR 1.8.6. These improvements are described in this report. To help understand the impact of the model improvements, a few severe accident scenario simulations were run and compared in this report.

\subsection{OBJECTIVES}

The high-level objectives of this work are to

- document recent changes made to the MELCOR Peach Bottom model at ORNL and

- illustrate the impact of the modeling changes on severe accident progression predictions.

\subsection{OVERVIEW OF TOOLS}

MELCOR is a system-level code that models the progression of severe accidents in light water nuclear power plants. It is developed and maintained by Sandia National Laboratories (SNL) for the U.S. Nuclear Regulatory Commission. The code encompasses various phenomena that can occur during a severe accident, including the thermal-hydraulic response, the heat up, degradation and relocation of the core material, transport of radionuclides, and hydrogen combustion. Although there are other uses, MELCOR is primarily used to estimate the source term from severe accidents. MELCOR version 1.8.5 was released in 2000 [8]; version 1.8.6 was released in 2005 [9]; and version 2.1 was released in 2008 [10]. A number of modeling improvements were made in between versions 1.8.5 and 1.8.6. One key modeling change was the treatment of the reactor vessel bottom head. From version 1.8.6 to 2.1, the major code improvements were related to internal structure and to input structure. This study uses the MELCOR 1.8.5 (RO) and MELCOR 1.8.6 (.4073) executables for Windows released by SNL. 



\section{PEACH BOTTOM MODEL UPGRADE DESCRIPTIONS}

The Peach Bottom model as described by Francis and Garvey [6,7] was used as the basis for the model. This section describes the modifications made to the model.

\subsection{UPGRADE FROM MELCOR 1.8.5 TO 1.8.6}

The MELCOR 1.8.5 Peach Bottom model has been updated for use in MELCOR 1.8.6. A converter utility, provided by SNL, was used to perform the update [11].

The primary difference between MELCOR 1.8.5 and 1.8.6 is the modeling treatment of the lower head. In MELCOR 1.8.5, the lower head is represented as a flat plate within the COR package, and the vessel structure is modeled separately in the HS package. There was an alternate lower head model for BWRs, developed at ORNL, that could be activated in MELCOR 1.8.5 (the BH package). In MELCOR 1.8.6, the lower head model within the COR package was modified to account for the curvature of the lower head and the area below the core barrel/shroud. The modifications also moved the structure modeling of the lower head into the COR package (instead of the HS package). The BH package was removed from MELCOR 1.8.6.

Tables A-1 to A-4 (in Appendix A) summarize the values used in the converter utility to re-nodalize the lower head and internal volumes to conform to the modeling methodology employed in MELCOR 1.8.6. The default user options were selected for all other utility input. The text file created by the converter utility was saved as "special.txt" and added to the list of input files for the Peach Bottom model. In addition to the modifications made by the utility for modeling the lower head, the changes noted in Table 1 were made to the Peach Bottom model.

Table 1. Summary of additional edits made to the model during upgrade from 1.8.5 to 1.8.6

\begin{tabular}{|c|c|}
\hline File & Edit \\
\hline jelly.cor & $\begin{array}{l}\text { Added: CORTST0100000000000000 } \\
\text { The optional CORTST01 record specifies switches to disable portions of the COR } \\
\text { package physics. This record contains additional options in MELCOR 1.8.6. This optional } \\
\text { input was included in the updated model. }\end{array}$ \\
\hline jelly.gen & $\begin{array}{l}\text { Added: } \quad \mathrm{R} * \mathrm{I}^{*} \mathrm{~F} \text { 'special.txt' } \\
\text { This is the file created by the 1.8.5-1.8.6 converter utility }\end{array}$ \\
\hline core.gen & 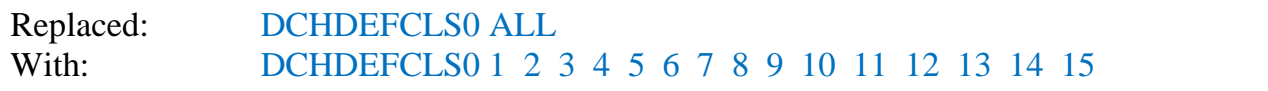 \\
\hline cf.gen & 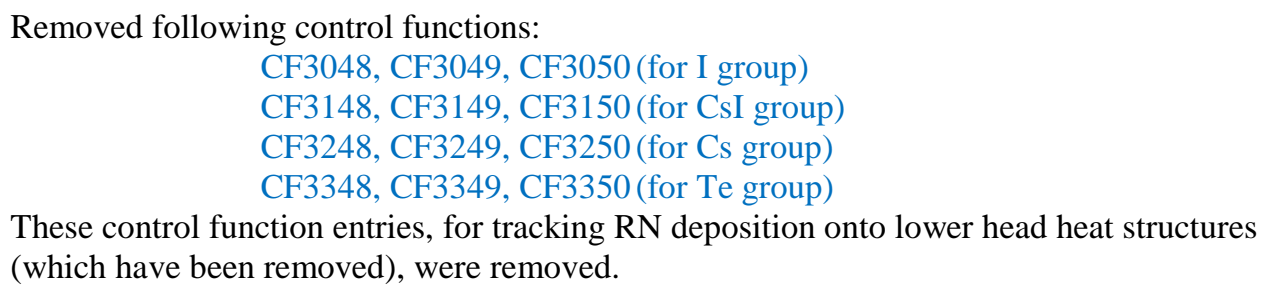 \\
\hline cf.gen & $\begin{array}{l}\text { Removed: CF821 } \\
\text { CF821 calculated heat flux from lower head to dry well CV105. However, heat structures } \\
\text { are no longer used to model lower head. Open for future development. CF821 is used in } \\
\text { CF822 and CF009. }\end{array}$ \\
\hline Cont-cvh.gen & In CF009, removed steady state dry well ventilation from CV105 \\
\hline
\end{tabular}




\subsection{INCREASED WET WELL DISCRETIZATION}

In the Peach Bottom model used by Francis and Garvey [6, 7], as well as the State-of-the-Art Reactor Consequence Analyses project (SOARCA) Peach Bottom model [12], the suppression pool was modeled using a single control volume. Using a single control volume effectively forces or assumes that the water is well mixed. However, studies from the 1980s suggest that phenomena such as localized saturation, thermal stratification, and complex convection cell formation could occur [13]. Localized saturation of the suppression pool water may occur if a single safety relief valve (SRV) is actuated repeatedly (e.g., repeated automatic actuation of the SRV with the lowest set point when manual control is unavailable). Localized saturation and thermal stratification of the suppression pool is important with respect to the effectiveness of condensing the injected steam (i.e., containment pressure) and radionuclide scrubbing capability (i.e., decontamination factor). To help account for such phenomena, the suppression pool was divided into eight control volumes. This was originally proposed and performed for the Fukushima Daiichi Accident Study [14, 15].

The single wet well control volume was divided into eight evenly-sized regions in the azimuthal direction (see Fig. B-1 in Appendix B). This also entailed modeling eight downcomers from the dry well to the wet well and adding additional heat structures and flow paths as appropriate. The azimuthal placement of the SRV steam injection locations, the high pressure coolant injection (HPCI) system, and the reactor core isolation cooling (RCIC) system suction and steam injection locations in the suppression pool were assumed. The logic that controls the manual SRV actuation to depressurize the reactor pressure vessel (RPV) due to diminished suppression chamber heat capacity was modified to depend on the average suppression pool water temperature. Similar control logic used in modeling other systems was also modified to depend on the average suppression pool water temperature. While the new discretization of the suppression pool allows for temperature variations azimuthally, it still cannot capture localized convection cells or saturation within control volumes, and it has not been validated against available experimental data. Therefore, suppression pool modeling in MELCOR remains an area for improvement.

\subsection{SRV CONTROL LOGIC MODIFICATION}

The logic for actuation of the SRVs was modified. The actuation pressure for the SRVs in the original Peach Bottom model was based on the pressure differential between the primary side and the wet well pressure in containment. Thus, as the pressure in the wet well increases, the actuation point of the SRVs increases, resulting in an increase in the primary system pressure. After discussions with Larry Ott of ORNL, the SRV actuation pressure was changed in the model to depend only on the primary system pressure (determined by CF100 in 'srv-fl.gen'). This modification is supported by the long-term trends in the Fukushima Daiichi Unit 3 primary and containment pressure data [15].

\subsection{ADDITIONAL SRV FAILURE MODE}

Additional failure logic for the SRV with the lowest set point was added to the model. The original model accounted for SRV failure after a specified number of SRV actuations (10 cycles) above a specified temperature (1000K). This same failure mechanism and modeling is used in the SOARCA Peach Bottom model [12]. An additional failure mechanism, stochastic failure, was added to the model. The SRV with the lowest set point is modeled to fail in the open position after 270 cycles. This is the same modeling approach used by the SOARCA Peach Bottom model which used a best estimate SRV stochastic failure value of 270 cycles (Ref. [12], Sect. 4.4.2.1). The new failure mode was only applied to the SRV with the lowest set point because this SRV would likely experience the highest number of cycles. The new stochastic failure mode is modeled using the new CF928 in 'seq-trip.gen' as well as the new CF222, CF219, CF217, CF215, and CF214 in 'srv-fl.gen.' CF928 specifies the number of SRV actuations until stochastic failure for the SRV is assumed to occur. The new control functions added to the 'srv-fl.gen' file 
keep track of the number of total number of actuations of the SRV with the lowest set point and causes the SRV to stick fully open if the number of cycles is greater than the number specified in CF928. 



\section{COMPARISON SIMULATIONS WITH AND WITHOUT MODEL UPGRADES}

The following sections investigate the impact of the model updates described in Sect. 3. First, the accident scenario selected as a basis for the comparison is described. Next, figures of merit are defined as the basis of the comparison. Finally, the accident scenario was run with and without the updates active in the Peach Bottom model, and the results were compared.

The comparisons were performed with models that contain all the updates except for the update being varied [i.e., in the MELCOR 1.8.5 vs 1.8.6 comparison, both models have the same wet well discretization (8 nodes), the updated SRV control logic, and new stochastic SRV failure mode]. Section 3.3 documents the comparison of MELCOR versions 1.8.5 and 1.8.6.

\subsection{ACCIDENT SCENARIO DESCRIPTION}

The long term station blackout (LTSBO) severe accident scenario was chosen for investigation. For the Peach Bottom LTSBO scenario, it is assumed that AC electrical power is lost at reactor shutdown; however, DC power from batteries is assumed to last $8 \mathrm{~h}$. Due to the loss of AC power, the reactor successfully shuts down (referenced as time zero). While DC power is maintained, the RCIC and/or HPCI can be used to inject cooling water into the primary system, and the SRVs can be manually actuated. After the loss of DC power, the ability to inject water ceases. The water in RPV eventually boils away, uncovering the core, leading to core degradation and melting. The core melt relocates to the reactor bottom head and eventually exits into containment. Containment failure eventually occurs, releasing radionuclides into the environment. The simulation is specified to end $32 \mathrm{~h}$ after reactor shutdown.

This accident scenario was used for the analyses as the accident sequence is influenced by the various systems which were modified in the model (SRV logic and failure, wet well, lower head).

\subsection{FIGURES OF MERIT}

The unmodified and the modified LTSBO simulation results are compared for specific figures of merit. The figures of merit defined for these analyses cover the timing of the various stages of the accident progression and total quantities of interest (flammable gas, radionuclides); these are summarized in Table 2.

\subsection{COMPARISON OF MELCOR VERSIONS 1.8.5 AND 1.8.6}

The LTSBO scenario using the MELCOR 1.8.5 Peach Bottom model (basecode: 1.8.5(A), 9/25/2000, development version: RO, compiled: 5/12/2005) was compared to the LTSBO scenario predicted by the updated Peach Bottom model for MELCOR 1.8.6 (1.86.4073) (base case). In general, the models and scenario are identical except for the changes made to update the Peach Bottom model from MELCOR 1.8.5 to 1.8 .6 .

The results of the figures of merit are summarized in Table 3. The reactor water level (Fig. 1), steam dome pressure (Fig. 2), containment dry well pressure (Fig. 3), and hydrogen generation (Fig. 4) are provided for both simulations. 
Table 2. Figures of merit for comparison for unmodified and modified LTSBO simulation results

\begin{tabular}{|c|c|c|c|}
\hline \multicolumn{3}{|c|}{ Figure of Merit } & Significance \\
\hline \multirow{6}{*}{ Timing } & \multicolumn{2}{|c|}{ First fuel failure (cladding gap release) } & First significant release of radionuclides from fuel \\
\hline & \multicolumn{2}{|l|}{$0.5 \mathrm{~kg}$ of $\mathrm{H}_{2}$ is generated } & Onset of hydrogen generation \\
\hline & \multicolumn{2}{|l|}{$100 \mathrm{~kg}$ of $\mathrm{H}_{2}$ is generated } & Significant combustible gas generated \\
\hline & \multicolumn{2}{|l|}{ Lower head failure } & Escalation of accident to ex-vessel \\
\hline & \multicolumn{2}{|c|}{ First deflagration in building } & Escalation of accident \\
\hline & \multicolumn{2}{|c|}{$0.5 \mathrm{~kg}$ of noble gas release to envir. } & Onset of radionuclide release to outside \\
\hline \multirow{7}{*}{ Total } & \multicolumn{2}{|c|}{$\mathrm{H}_{2}$ gas generated by end of simulation } & Flammable gas potential \\
\hline & \multicolumn{2}{|c|}{ CO gas generated by end of simulation } & Flammable gas potential \\
\hline & \multirow{5}{*}{$\begin{array}{l}\text { Radionuclide mass } \\
\text { released to environment } \\
\text { by end of simulation* }\end{array}$} & Class $1(\mathrm{Xe})$ & Source term (largest contribution) \\
\hline & & Class $2(\mathrm{Cs})$ & Source term (Cs important for risk) \\
\hline & & Class $3(\mathrm{Ba})$ & Source term (Sr important for risk) \\
\hline & & Class 4 (I) & Source term (I important for risk) \\
\hline & & Class $16(\mathrm{CsI})$ & Source term (CsI to account for all Cs and I) \\
\hline
\end{tabular}

*See MELCOR Computer Code Manuals, Version 1.8.5, NUREG/CR-6119, Rev. 2, Sandia National

Laboratories, Albuquerque, N.M., October 2000, for a summary of the constituents of the radionuclide classes.

In general, the model and executables of both MELCOR versions produce similar results. There is a slight difference in the boil-down rate once the water level reaches the lower head (Fig. 1). This can be attributed to the fact that MELCOR 1.8.5 predicts a slightly earlier melt relocation into the lower plenum than MELCOR 1.8.6. The reactor pressure is predicted to be very similar until about $14 \mathrm{~h}$ after the accident initiation (Fig. 2). The difference, again, lies in the different timing of the major relocation of the core melt into the lower plenum. MELCOR 1.8.5 that predicts the core plate will fail around $14 \mathrm{~h}$, while MELCOR 1.8.6 predicts that the plate will fail around the 15-h mark. One noticeable difference is the timing of lower head failure. MELCOR 1.8.5 predicts that the lower head will fail around $16.9 \mathrm{~h}$; MELCOR 1.8.6 predicts failure around 21.6 h. Both versions predict the same lower head failure mechanism, failure of a penetration. The difference in timing is attributed to differences in the modeling mythologies of the bottom head in MELCOR 1.8.5 vs MELCOR 1.8.6. The timing of the first deflagration, usually corresponding to containment failure and resulting in radionuclide release, is similar in the two models, despite the differences in lower head failure timing. The amount of flammable gas is similar in the models (Fig. 4). The amount of noble gases released by the end of the simulation (32 h) is within $1 \%$ of one another. However, the radionuclide releases of other groups (barium, cesium, iodine, cesium iodide) by the end of the simulation vary substantially. 
Table 3. Comparison of results from MELCOR Versions 1.8.5 and 1.8.6

\begin{tabular}{|c|c|c|c|c|c|}
\hline & \multirow{2}{*}{\multicolumn{2}{|c|}{ Figure of Merit }} & \multicolumn{2}{|c|}{ MELCOR Version } & \multirow{2}{*}{$\begin{array}{l}\text { Percent } \\
\text { Difference }\end{array}$} \\
\hline & & & $1.8 .6^{*}$ & 1.8 .5 & \\
\hline \multirow{6}{*}{$\begin{array}{l}\text { Timing } \\
\text { (h) }\end{array}$} & \multicolumn{2}{|c|}{ First fuel failure (clad. gap release) } & 12.3 & 12.1 & $-1.6 \%$ \\
\hline & \multicolumn{2}{|c|}{$0.5 \mathrm{~kg}$ of $\mathrm{H}_{2}$ is generated } & 12.3 & 12.1 & $-1.5 \%$ \\
\hline & \multicolumn{2}{|c|}{$100 \mathrm{~kg}$ of $\mathrm{H}_{2}$ is generated } & 12.6 & 12.4 & $-1.5 \%$ \\
\hline & \multicolumn{2}{|c|}{ Lower head failure } & 21.6 & 16.9 & $-21.6 \%$ \\
\hline & \multicolumn{2}{|c|}{ First deflagration in building } & 21.8 & 21.1 & $-3.6 \%$ \\
\hline & \multicolumn{2}{|c|}{$0.5 \mathrm{~kg}$ of noble gas release to envir. } & 21.8 & 21.1 & $-3.6 \%$ \\
\hline \multirow{7}{*}{$\begin{array}{l}\text { Total } \\
(\mathrm{kg})\end{array}$} & \multicolumn{2}{|c|}{$\mathrm{H}_{2}$ gas generated by end of sim. } & 1482 & 1523 & $2.8 \%$ \\
\hline & \multicolumn{2}{|c|}{ CO gas generated by end of sim. } & 21121 & 26672 & $26.3 \%$ \\
\hline & \multirow{5}{*}{$\begin{array}{l}\text { Radionuclide } \\
\text { mass released to } \\
\text { environment by } \\
\text { end of } \\
\text { simulation** }\end{array}$} & Class $1(\mathrm{Xe})$ & $4.27 \mathrm{E}+02$ & $4.25 \mathrm{E}+02$ & $-0.6 \%$ \\
\hline & & Class $2(\mathrm{Cs})$ & $3.17 \mathrm{E}+00$ & $4.95 \mathrm{E}+00$ & $56.0 \%$ \\
\hline & & Class $3(\mathrm{Ba})$ & $1.12 \mathrm{E}+01$ & $2.26 \mathrm{E}+01$ & $101.8 \%$ \\
\hline & & Class 4 (I) & $9.70 \mathrm{E}-03$ & $1.65 \mathrm{E}-02$ & $70.5 \%$ \\
\hline & & Class $16(\mathrm{CsI})$ & $2.34 \mathrm{E}+00$ & $5.29 \mathrm{E}+00$ & $125.8 \%$ \\
\hline
\end{tabular}

* Base case; MELCOR 1.8.6; Eight wet well control volumes, modified safety relief valve (SRV) logic, and stochastic SRV failure.

**See MELCOR Computer Code Manuals, Version 1.8.5, NUREG/CR-6119, Rev. 2, Sandia National Laboratories, Albuquerque, N.M., October 2000, for a summary of the constituents of the radionuclide classes.

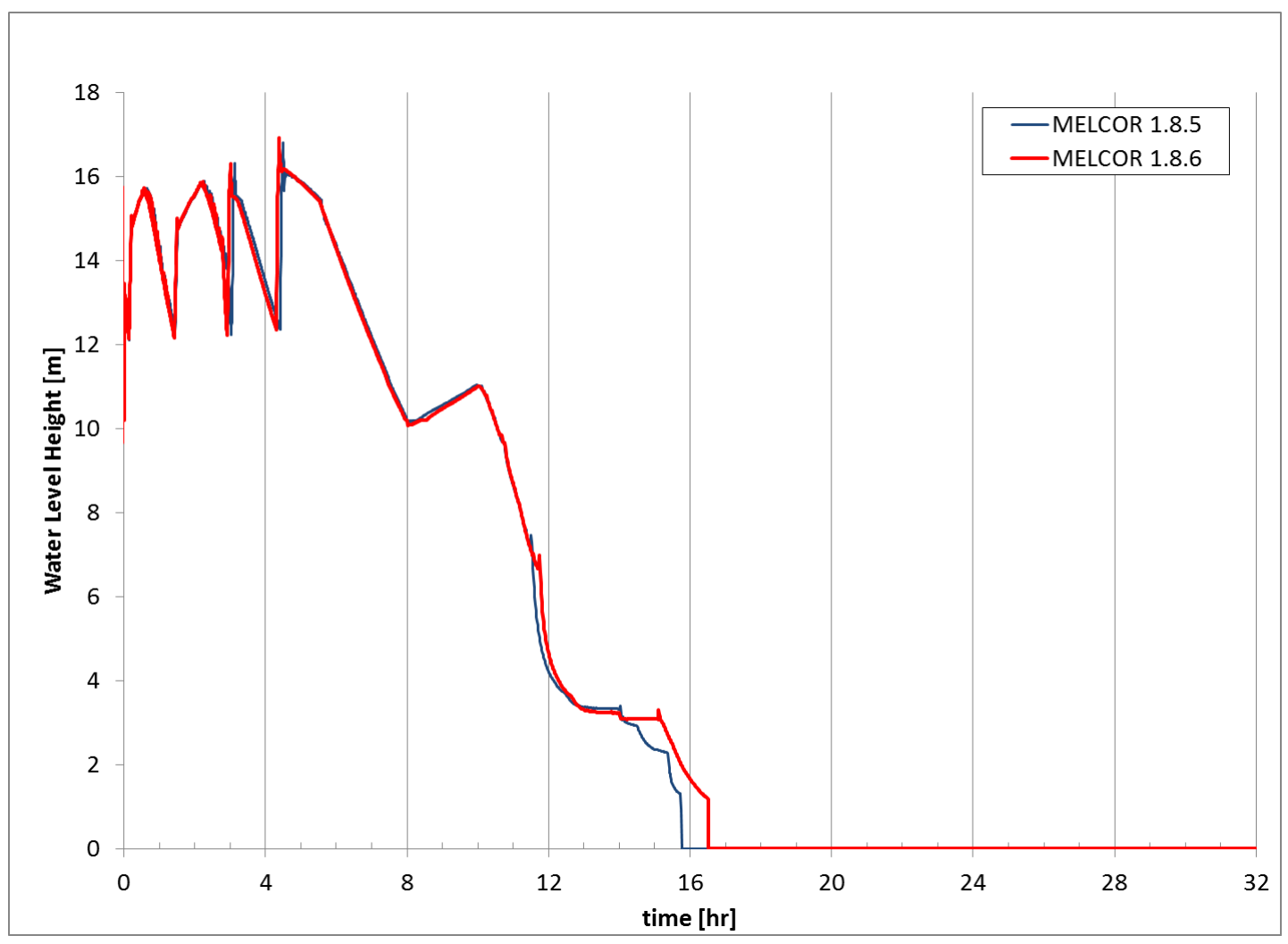

Fig. 1. Reactor water level response, MELCOR 1.8.6 vs MELCOR 1.8.5. 


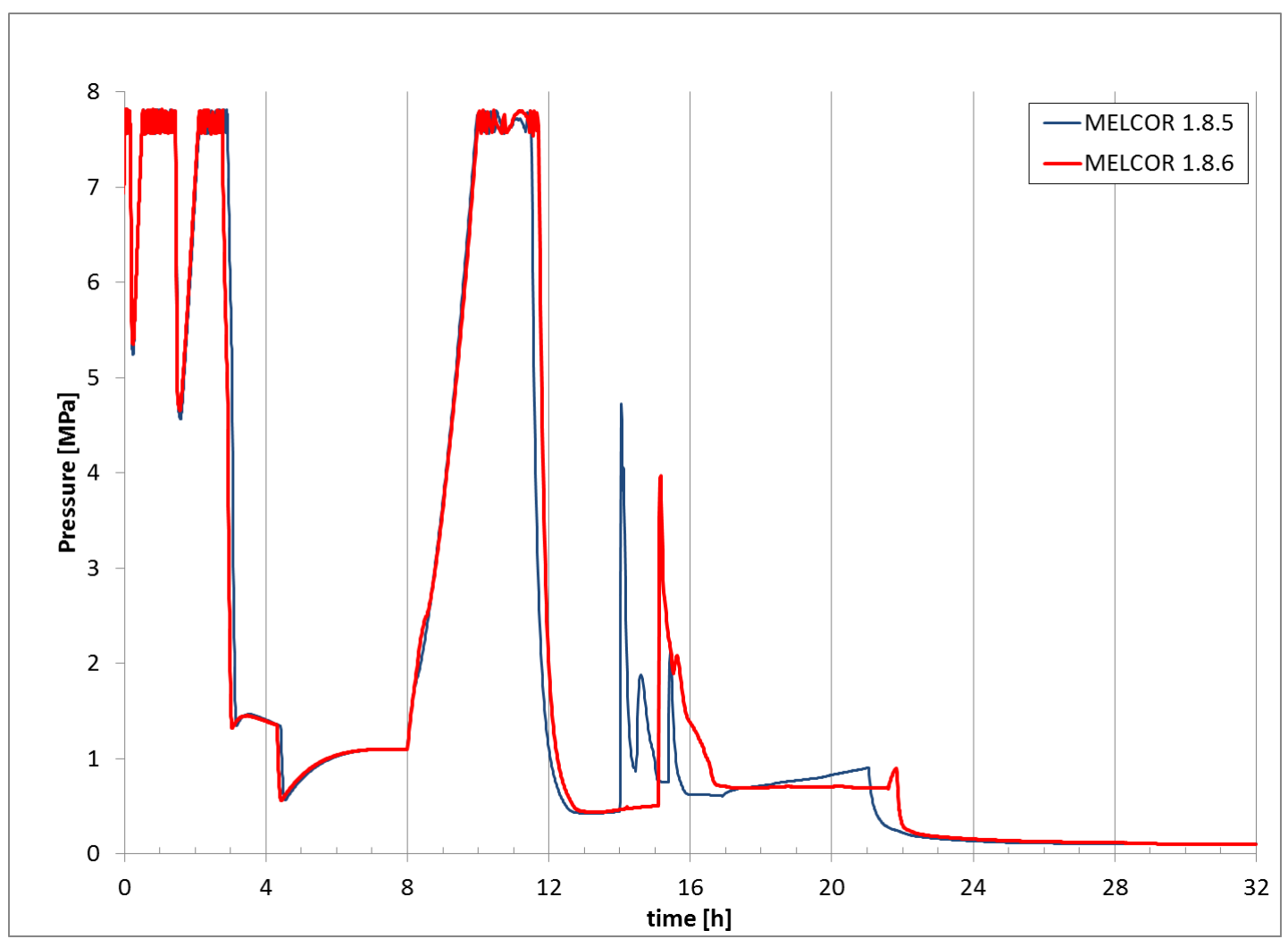

Fig. 2. Reactor pressure response, MELCOR 1.8.6 vs MELCOR 1.8.5.

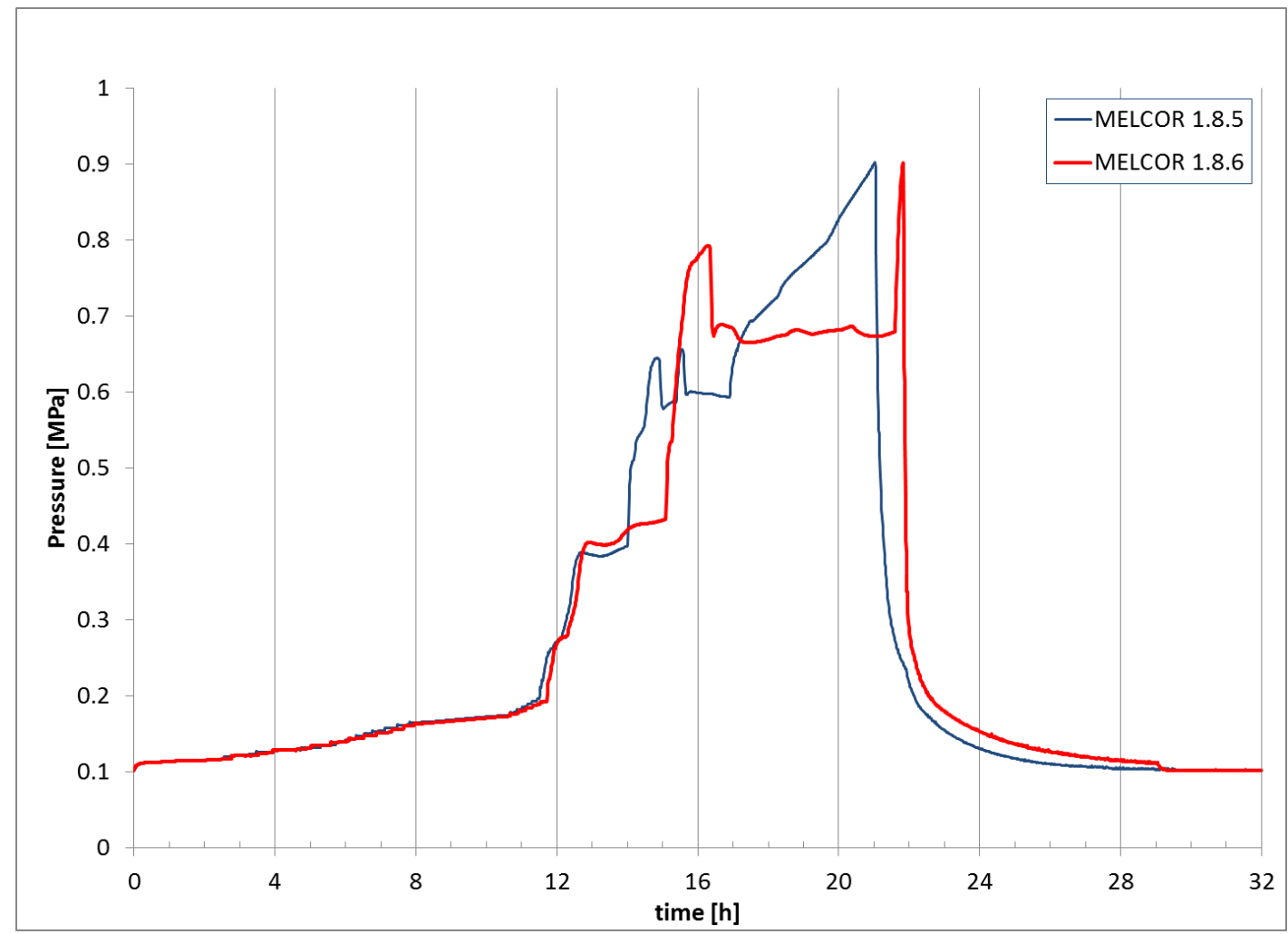

Fig. 3. Containment pressure response, MELCOR 1.8.6 vs MELCOR 1.8.5. 




Fig. 4. Hydrogen generation response, MELCOR 1.8.6 vs MELCOR 1.8.5.

\subsection{COMPARISON OF ONE VS EIGHT WET WELL CONTROL VOLUMES}

A comparison was made of the LTSBO scenario with models using one and eight (base case) control volumes to model the suppression pool; this comparison is described in Sect. 2.2.

The results of the figures of merit are summarized in Table 4 for both simulations. The reactor water level (Fig. 5), steam dome pressure (Fig. 6), containment dry well pressure (Fig. 7), and total hydrogen production (Fig. 8) are provided for both simulations.

For the case where the suppression pool is modeled with eight control volumes, the suppression pool reaches high temperature approximately $15 \mathrm{~min}$ earlier than the case using one control volume. This is due to the localized heating of the pool in the eight control volume case instead of homogenous heating of the pool in the one control volume case. This results in the operators depressurizing the primary system approximately $15 \mathrm{~min}$ earlier due to reaching the pool heat capacity limits. The earlier depressurization reduces the number of SRV cycles early on and results in a later (approximately $20 \mathrm{~min}$ ) failure time of the lowest set point SRV due to stochastic failure. These two occurrences, the earlier RPV depressurization by operators and the later SRV failure, cause shifts in the accident progression.

Early in the accident, the containment pressure is unaffected by the suppression pool nodalization. After SRV failure and RPV depressurization, the containment pressure response between the two cases diverges. As expected, the case using eight control volumes to model the suppression pool attains higher containment pressures due to the decreased cooling/steam condensing performance of the pool caused by localized heating and saturation in the suppression pool. The early localized saturation of the pool is shown in Fig. 9. In contrast, when modeling the suppression pool using only one control volume, the pool stays subcooled to nearly $22.5 \mathrm{~h}$, at which time containment fails and depressurizes (Fig. 10). 
Table 4. Suppression Pool Discretization Result Summary

\begin{tabular}{|c|c|c|c|c|c|}
\hline \multicolumn{3}{|c|}{ Figure of Merit } & $\begin{array}{l}\text { Eight } \\
\text { Control } \\
\text { Volumes* }\end{array}$ & $\begin{array}{l}\text { One } \\
\text { Control } \\
\text { Volume }\end{array}$ & $\begin{array}{l}\text { Percent } \\
\text { Difference }\end{array}$ \\
\hline \multirow{6}{*}{$\begin{array}{l}\text { Timing } \\
\text { (h) }\end{array}$} & \multicolumn{2}{|c|}{ First fuel failure (clad. gap release) } & 12.3 & 12.1 & $-2.1 \%$ \\
\hline & \multicolumn{2}{|c|}{$0.5 \mathrm{~kg}$ of $\mathrm{H}_{2}$ is generated } & 12.3 & 12.0 & $-2.0 \%$ \\
\hline & \multicolumn{2}{|c|}{$100 \mathrm{~kg}$ of $\mathrm{H}_{2}$ is generated } & 12.6 & 12.4 & $-2.0 \%$ \\
\hline & \multicolumn{2}{|l|}{ Lower head failure } & 21.6 & 22.3 & $3.3 \%$ \\
\hline & \multicolumn{2}{|c|}{ First deflagration in building } & 21.8 & 22.5 & $3.2 \%$ \\
\hline & \multicolumn{2}{|c|}{$0.5 \mathrm{~kg}$ of noble gas release to envir. } & 21.8 & 22.5 & $3.1 \%$ \\
\hline \multirow{7}{*}{$\begin{array}{l}\text { Total } \\
(\mathrm{kg})\end{array}$} & \multicolumn{2}{|c|}{$\mathrm{H}_{2}$ gas generated by end of sim. } & 1482 & 1403 & $-5.3 \%$ \\
\hline & \multicolumn{2}{|c|}{ CO gas generated by end of sim. } & 21121 & 20695 & $-2.0 \%$ \\
\hline & \multirow{5}{*}{$\begin{array}{l}\text { Radionuclide mass } \\
\text { released to } \\
\text { environment by } \\
\text { end of } \\
\text { simulation** }\end{array}$} & Class $1(\mathrm{Xe})$ & $4.27 \mathrm{E}+02$ & $4.28 \mathrm{E}+02$ & $0.2 \%$ \\
\hline & & Class $2(\mathrm{Cs})$ & $3.17 \mathrm{E}+00$ & $4.44 \mathrm{E}+00$ & $39.8 \%$ \\
\hline & & Class $3(\mathrm{Ba})$ & $1.12 \mathrm{E}+01$ & $1.31 \mathrm{E}+01$ & $16.5 \%$ \\
\hline & & Class $4(\mathrm{I})$ & 9.70E-03 & $2.46 \mathrm{E}-03$ & $-74.7 \%$ \\
\hline & & Class $16(\mathrm{CsI})$ & $2.34 \mathrm{E}+00$ & $1.72 \mathrm{E}+00$ & $-26.5 \%$ \\
\hline
\end{tabular}

*Base case; MELCOR 1.8.6, Eight wet well control volumes, modified safety relief valve (SRV) logic, and stochastic SRV failure.

**See MELCOR Computer Code Manuals, Version 1.8.5, NUREG/CR-6119, Rev. 2, Sandia National Laboratories, Albuquerque, N.M., October 2000, for a summary of the constituents of the radionuclide classes



Fig. 5. Reactor water level response, eight vs one pool control volumes. 


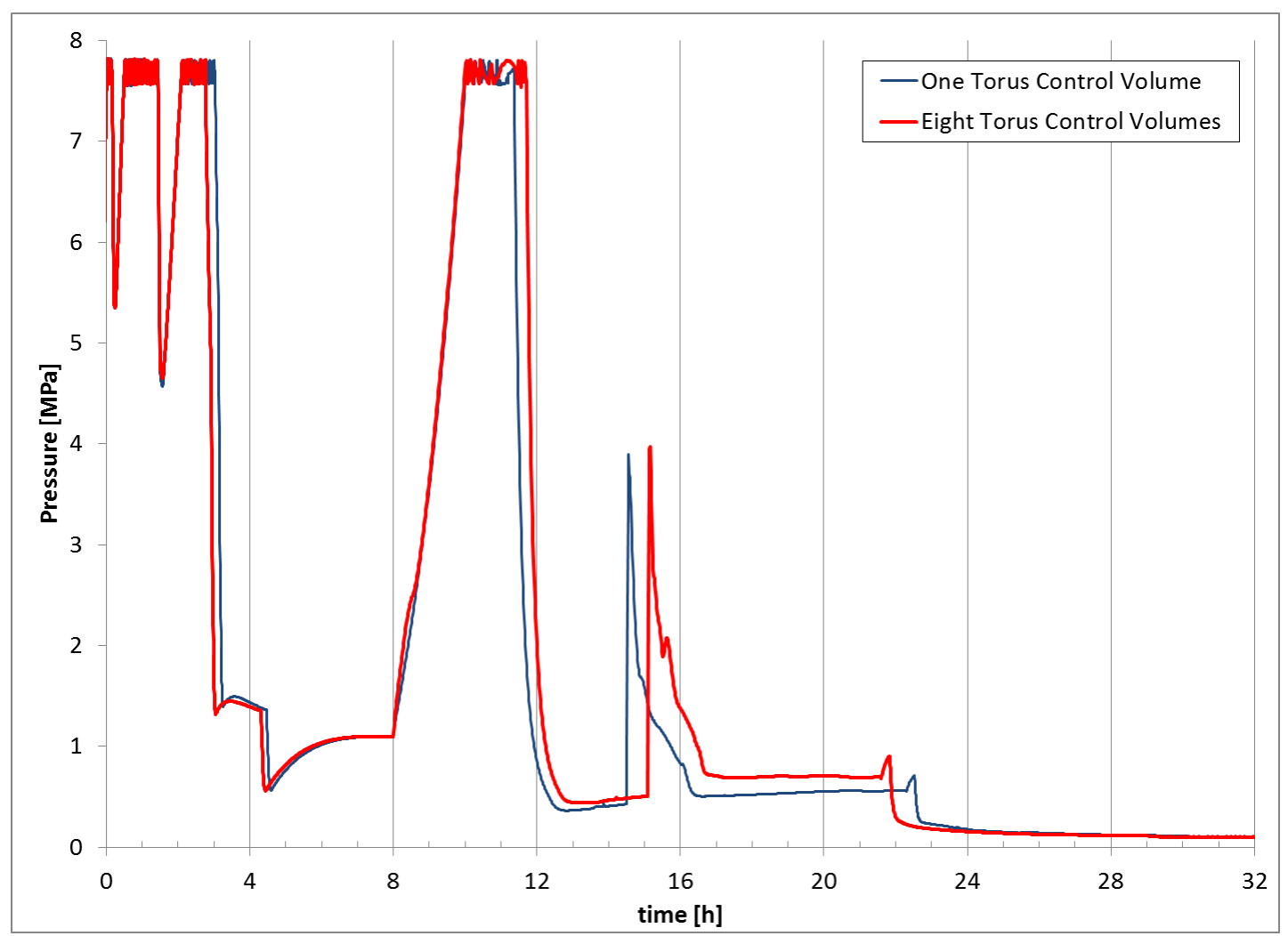

Fig. 6. Reactor pressure response, eight vs one pool control volumes.

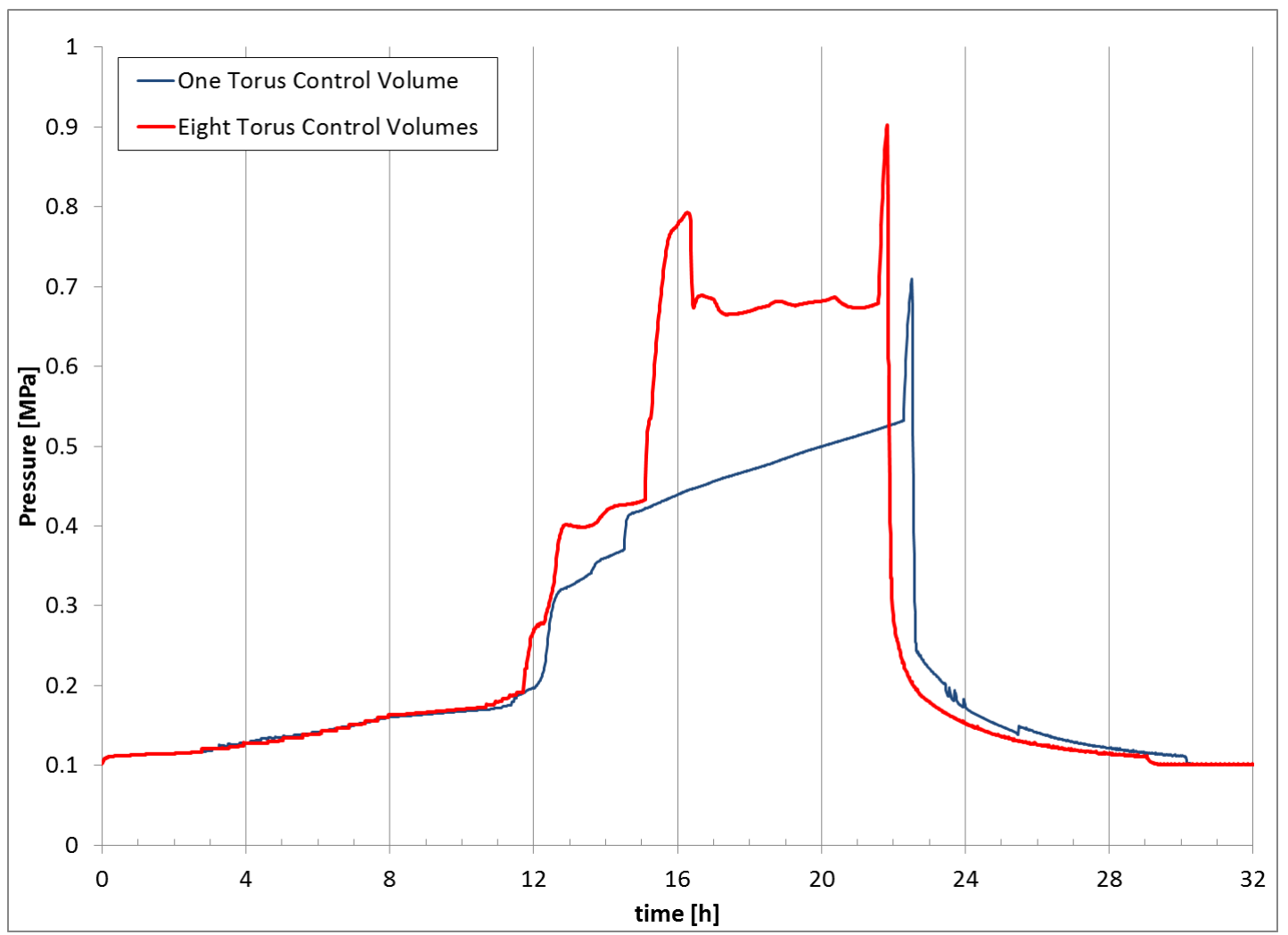

Fig. 7. Containment pressure response, eight vs one pool control volumes. 


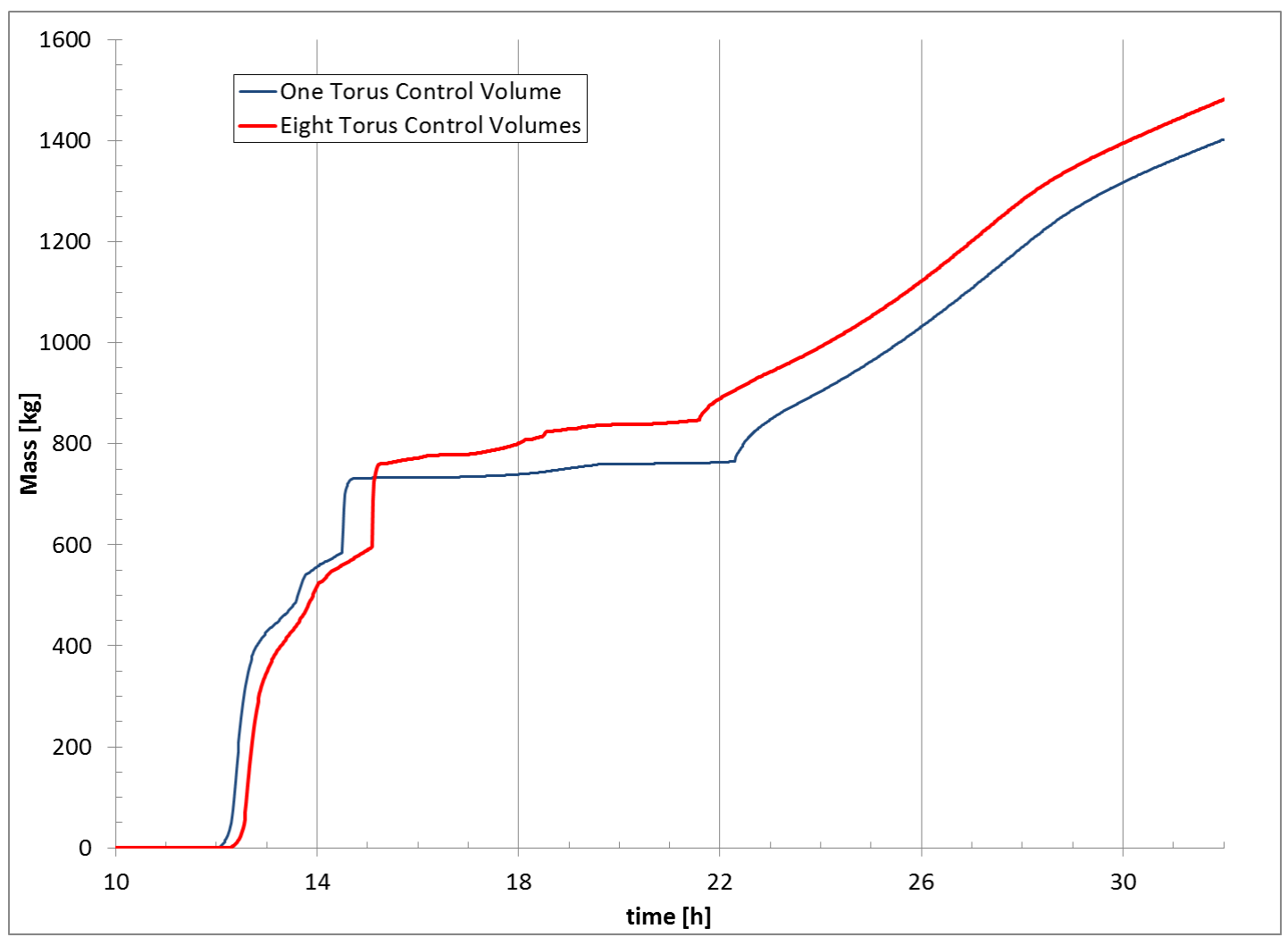

Fig. 8. Hydrogen generation response, eight vs one pool control volumes.

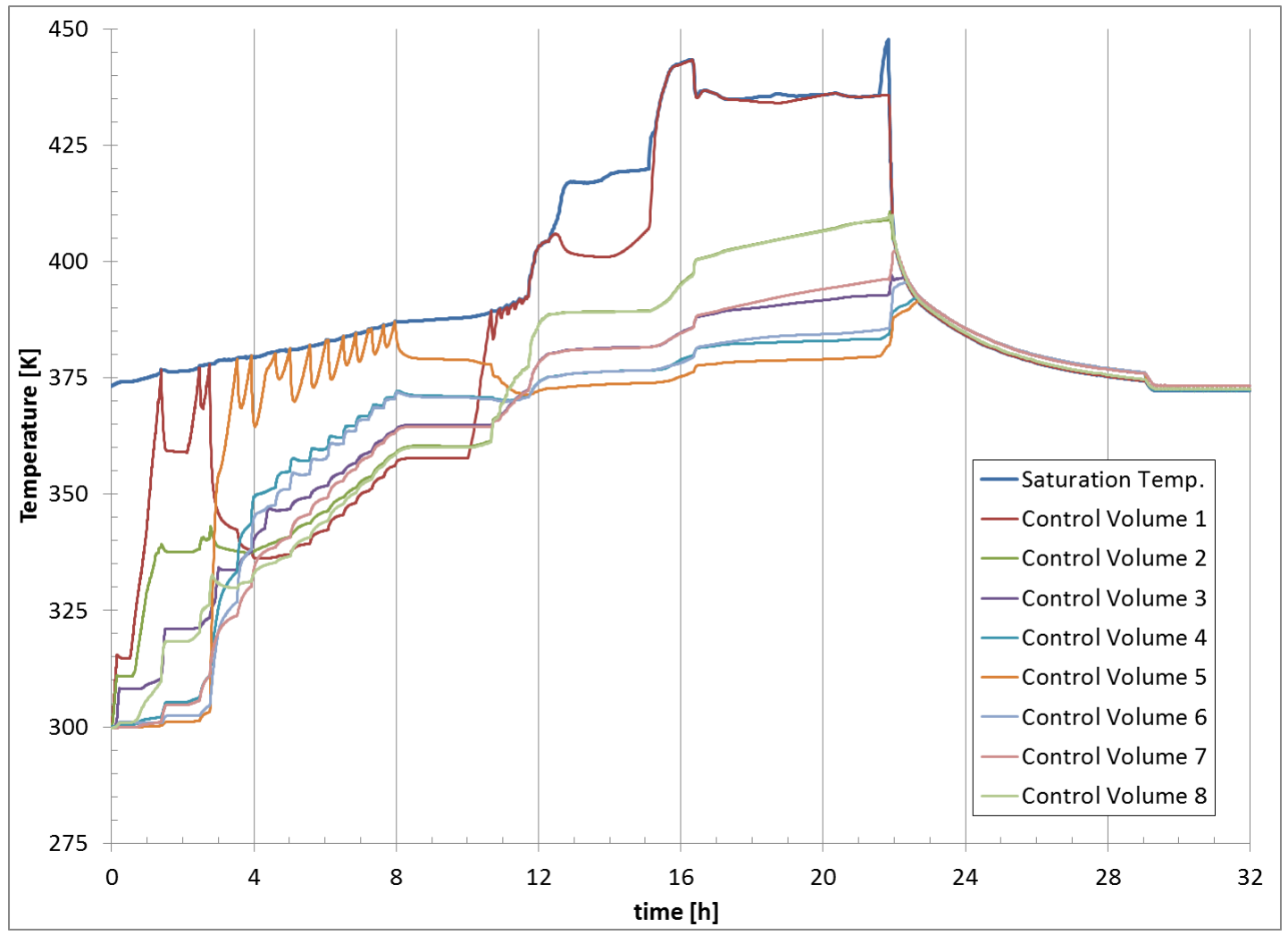

Fig. 9. Suppression pool temperature response, eight pool control volumes. 


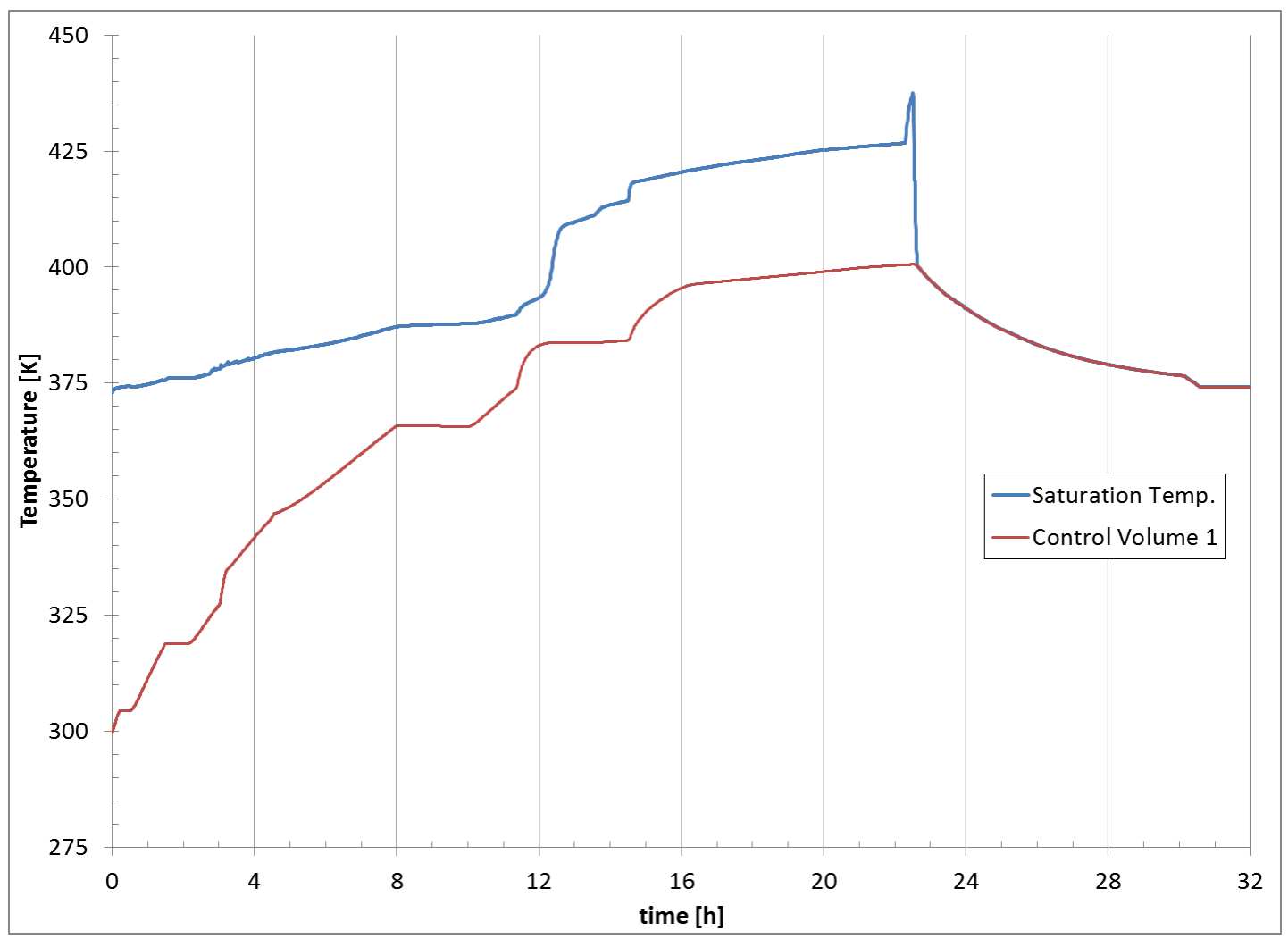

Fig. 10. Suppression pool temperature response, one pool control volumes.

\subsection{COMPARISON OF SRV CONTROL LOGIC}

A comparison was made of the LTSBO scenario with the base case and without the modified SRV actuation logic described in Sect. 2.3.

The results of the figures of merit are summarized in Table 5 for both simulations. The reactor water level (Fig. 11), steam dome pressure (Fig. 12), containment dry well pressure (Fig. 13), and total hydrogen production (Fig. 14) are provided for both simulations.

In general, both models produce very similar results. As seen in Fig. 12, the reactor pressure is slightly higher and increases over time in the model which uses the unmodified SRV logic. The difference in reactor pressure has a very minor impact on the boil down rate and containment pressure. Interestingly, the change in logic did have an impact on the overall flammable gas production. The lower head is predicted to fail approximately $2 \mathrm{~h}$ earlier in the model with unmodified SRV logic than in the modified model. The earlier melt release results in relocating a cooler melt (approximately $1770 \mathrm{~K}$ vs $2320 \mathrm{~K}$, Fig. 15). The parametric spreading routine incorporated into the Peach Bottom model predicts that the cooler melt will cover much less area $\left(67.5 \mathrm{~m}^{2}\right.$ vs $\left.103 \mathrm{~m}^{2}\right)$ in the dry well than the hotter melt (Fig. 16). See Ref. [18] for further discussion on spreading modeling. The cooler melt and reduced spreading area result in less flammable gas generation ex-vessel. 
Table 5. Safety relief valve control logic modification result summary

\begin{tabular}{|c|c|c|c|c|c|}
\hline \multicolumn{3}{|c|}{ Figure of Merit } & $\begin{array}{l}\text { Modified } \\
\text { Logic* }\end{array}$ & $\begin{array}{l}\text { Unmodified } \\
\text { Logic }\end{array}$ & $\begin{array}{l}\text { Percent } \\
\text { Difference }\end{array}$ \\
\hline \multirow{6}{*}{$\begin{array}{l}\text { Timing } \\
\text { (h) }\end{array}$} & \multicolumn{2}{|c|}{ First fuel failure (clad. gap release) } & 12.3 & 12.2 & $-1.4 \%$ \\
\hline & \multicolumn{2}{|c|}{$0.5 \mathrm{~kg}$ of $\mathrm{H}_{2}$ is generated } & 12.3 & 12.1 & $-1.4 \%$ \\
\hline & \multicolumn{2}{|c|}{$100 \mathrm{~kg}$ of $\mathrm{H}_{2}$ is generated } & 12.6 & 12.4 & $-1.3 \%$ \\
\hline & \multicolumn{2}{|l|}{ Lower head failure } & 21.6 & 19.7 & $-8.5 \%$ \\
\hline & \multicolumn{2}{|c|}{ First deflagration in building } & 21.8 & 21.9 & $0.3 \%$ \\
\hline & \multicolumn{2}{|c|}{$0.5 \mathrm{~kg}$ of noble gas release to envir. } & 21.8 & 21.9 & $0.3 \%$ \\
\hline \multirow{7}{*}{$\begin{array}{l}\text { Total } \\
(\mathrm{kg})\end{array}$} & \multicolumn{2}{|c|}{$\mathrm{H}_{2}$ gas generated by end of sim. } & 1482 & 1239 & $-16.4 \%$ \\
\hline & \multicolumn{2}{|c|}{ CO gas generated by end of sim. } & 21121 & 15672 & $-25.8 \%$ \\
\hline & \multirow{5}{*}{$\begin{array}{l}\text { Radionuclide mass } \\
\text { released to } \\
\text { environment by } \\
\text { end of } \\
\text { simulation** }\end{array}$} & Class $1(\mathrm{Xe})$ & $4.27 \mathrm{E}+02$ & $4.25 \mathrm{E}+02$ & $-0.6 \%$ \\
\hline & & Class $2(\mathrm{Cs})$ & $3.17 \mathrm{E}+00$ & $9.61 \mathrm{E}-01$ & $-69.7 \%$ \\
\hline & & Class $3(\mathrm{Ba})$ & $1.12 \mathrm{E}+01$ & $1.60 \mathrm{E}+01$ & $42.9 \%$ \\
\hline & & Class $4(\mathrm{I})$ & $9.70 \mathrm{E}-03$ & $1.60 \mathrm{E}-02$ & $64.9 \%$ \\
\hline & & Class $16(\mathrm{CsI})$ & $2.34 \mathrm{E}+00$ & $2.40 \mathrm{E}+00$ & $2.3 \%$ \\
\hline
\end{tabular}

*Base case; MELCOR 1.8.6, Eight wet well control volumes, modified safety relief valve (SRV) logic, and stochastic SRV failure.

**See MELCOR Computer Code Manuals, Version 1.8.5, NUREG/CR-6119, Rev. 2, Sandia National Laboratories, Albuquerque, N.M., October 2000, for a summary of the constituents of the radionuclide classes.

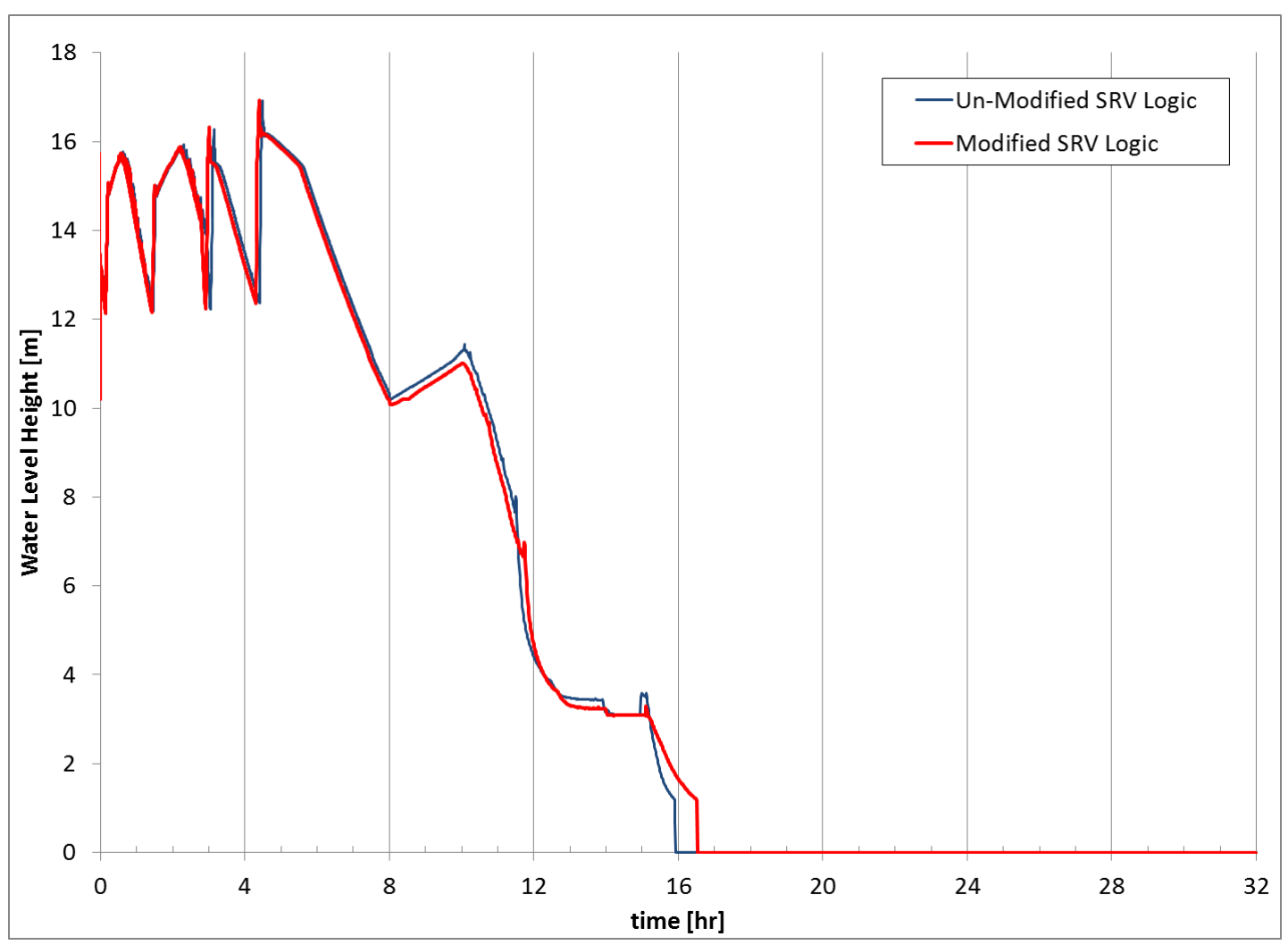

Fig. 11. Reactor water level response, modified vs unmodified safety relief valve logic. 


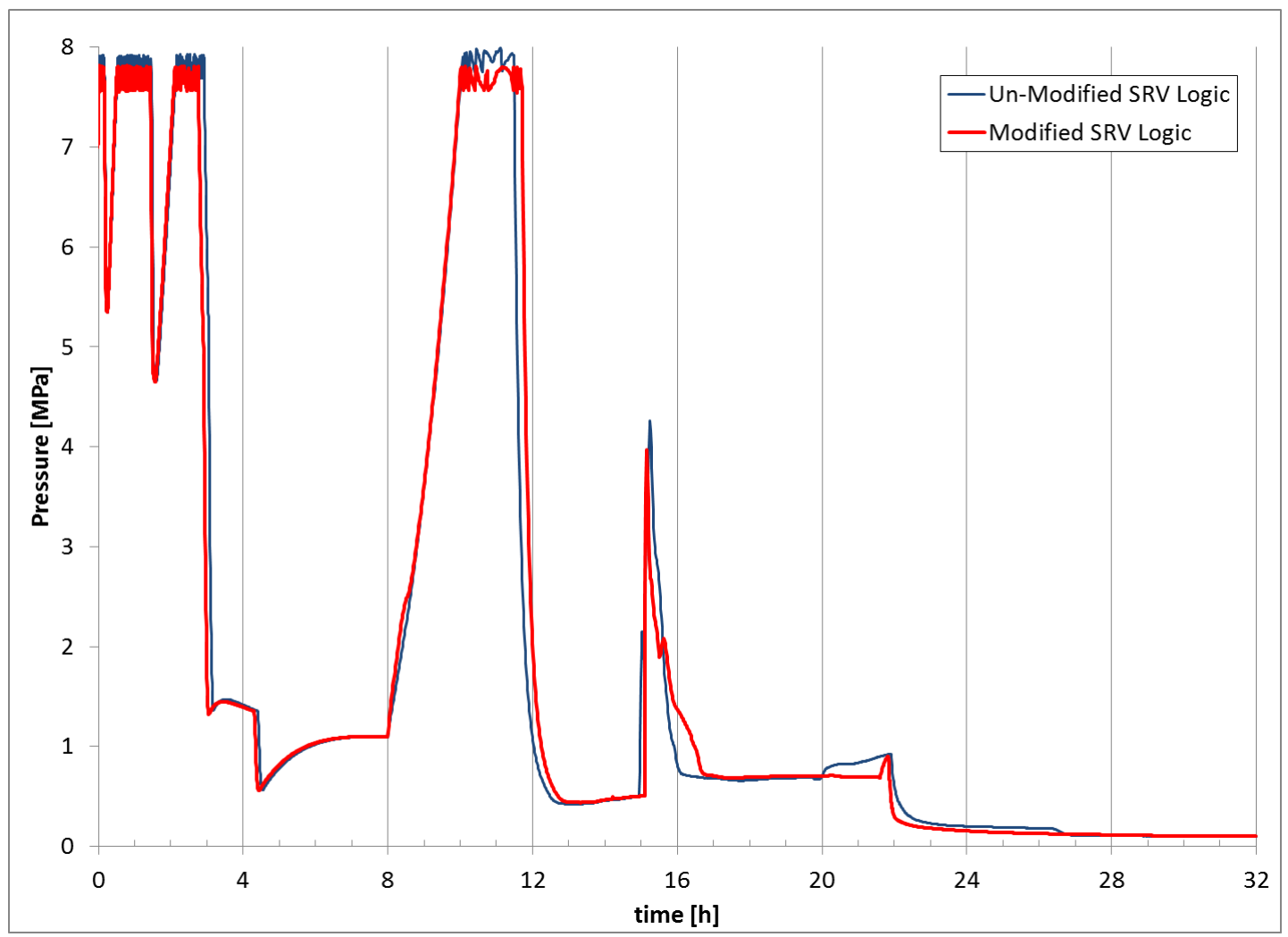

Fig. 12. Reactor pressure response, modified vs unmodified safety relief valve logic.

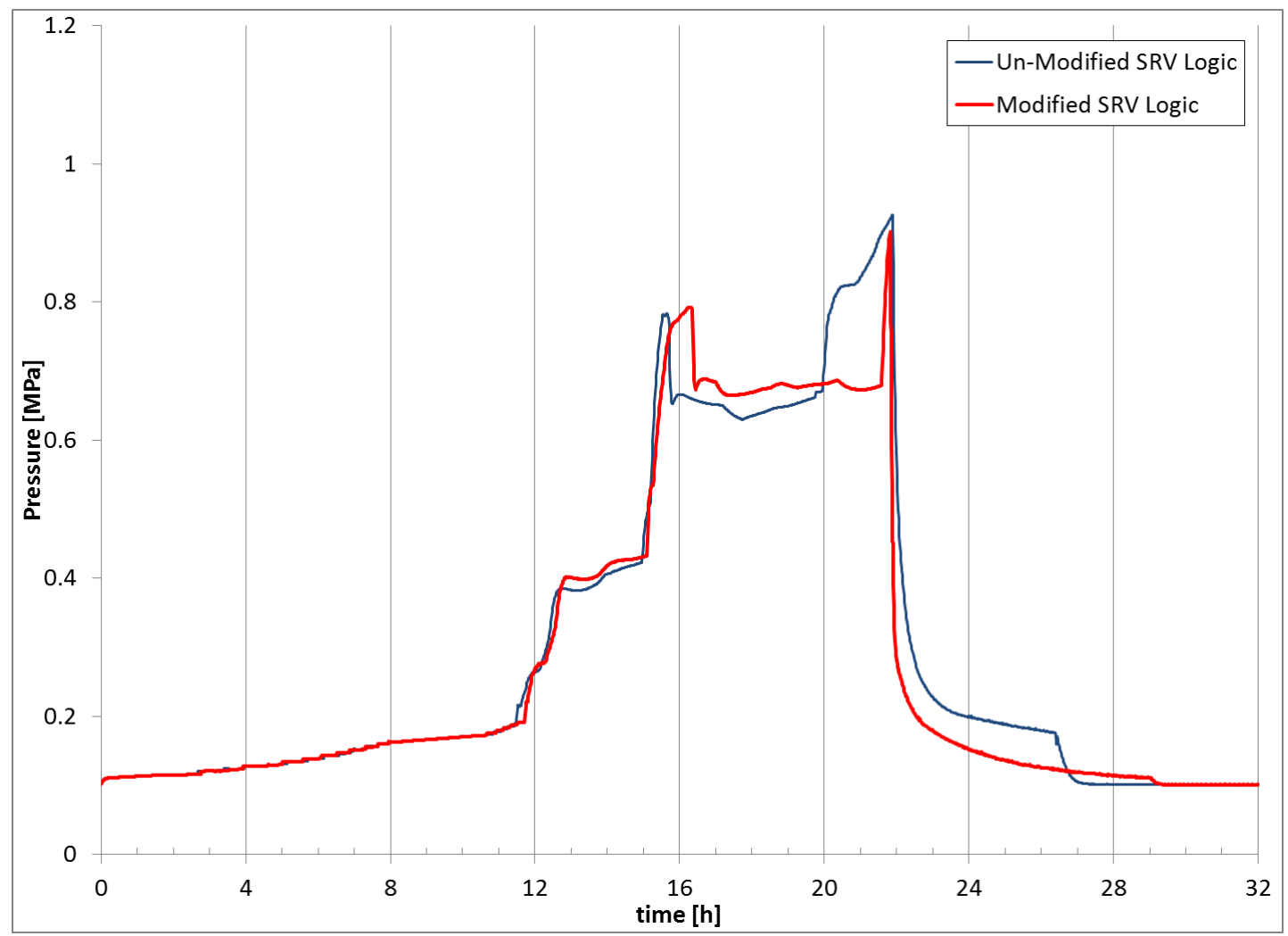

Fig. 13. Containment pressure response, modified vs unmodified safety relief valve logic. 


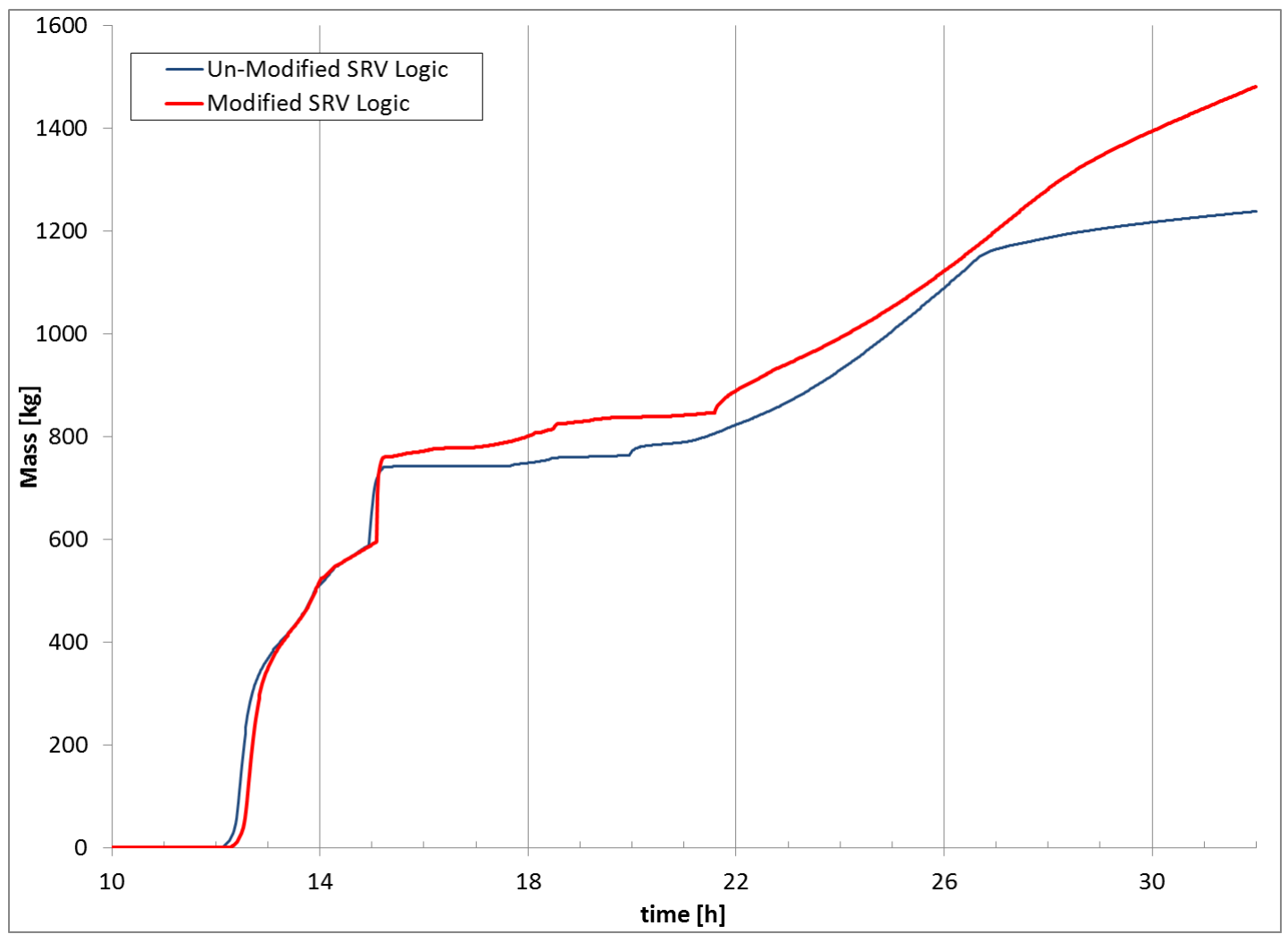

Fig. 14. Hydrogen generation response, modified vs unmodified safety relief valve logic.

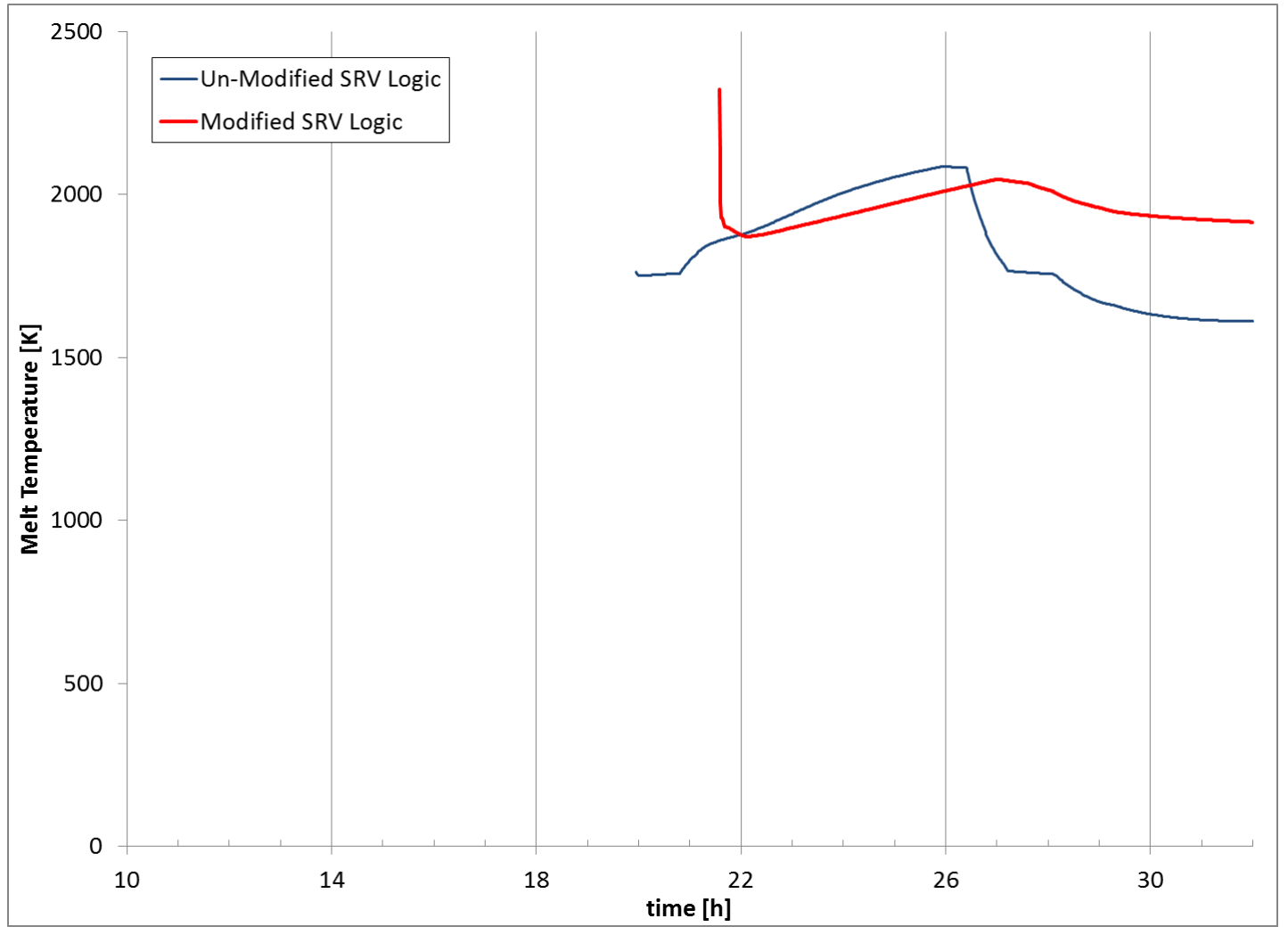

Fig. 15. Core melt temperature in pedestal region, modified vs unmodified safety relief valve logic. 


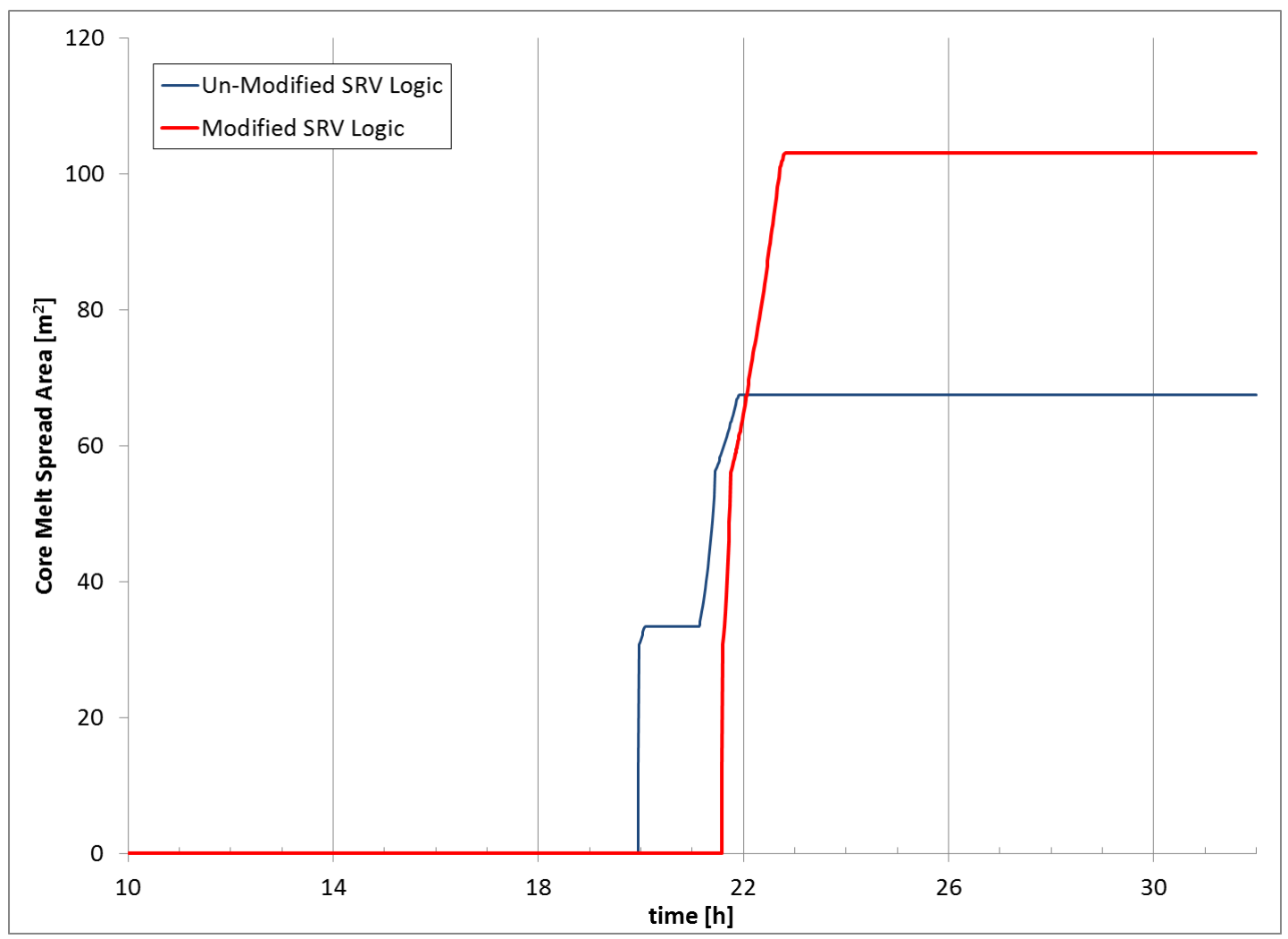

Fig. 16. Core melt spread area, modified vs unmodified safety relief valve logic.

\subsection{COMPARISON OF SRV FAILURE MODES}

A comparison was made of the LTSBO scenario with various SRV failure modes activated. The base case includes the thermal and stochastic SRV failure modes discussed in Sect. 2.4. Another case only had the original thermal SRV failure mode activated. Finally, a case was run in which both SRV failure modes were disabled.

The results of the figures of merit for both simulations are summarized in Tables 6 and 7, with additional information summarized in Table 8. The reactor water level (Fig. 17), steam dome pressure (Fig. 18), containment dry well pressure (Fig. 19), and total hydrogen production (Fig. 20) are provided for both simulations.

When both the stochastic and thermal (several cycles at high temperature) failure modes are active, the stochastic failure mode is predicted to occur first after 270 cycles, $11.7 \mathrm{~h}$ into the accident, in the SRV with the lowest set point. When only the thermal SRV failure mode is active, the SRV with the lowest set point is predicted to fail after 422 cycles, at $15.3 \mathrm{~h}$ into the accident. Finally, with no SRV failure modes active, the RPV eventually fails $23.1 \mathrm{~h}$ into the accident, at which time the SRV with the lowest set point has accumulated 803 cycles. The cumulative number of SRV cycles over time for the SRV with the lowest set point is provided in Fig. 21 for the three cases.

The timing of RPV depressurization (SRV or RPV failure) has a significant effect on the subsequent accident progression. Depressurization during the boildown phase affects the water level and the amount of steam passing through the core. This in turn affects cladding oxidation, which affects the generation of heat and hydrogen, melt relocation, and the timing of the bottom head failure. One such interplay of timing and phenomena is the failure mode of the bottom head. For the two cases where an SRV fails 
before the RPV depressurizes, the bottom head is predicted to fail by penetration failure. However, in the case where SRV failure is precluded, the RPV stays pressurized and fails, at high pressure, due to heat up and yielding of the bottom head. Stemming from this complicated interplay between timing and phenomena, the case where only the thermal SRV failure mode was active resulted in the earliest lower head failure, hottest core melt pour temperature (affecting melt spreading and core-concrete interaction), earliest containment failure, and earliest external radionuclide releases.

Table 6. Safety relief valve failure modes result summary (1)

\begin{tabular}{|c|c|c|c|c|c|}
\hline \multirow{2}{*}{ Figure of Merit } & \multirow{2}{*}{\multicolumn{2}{|c|}{ Figure of Merit }} & \multicolumn{2}{|c|}{ SRV Failure Mode } & \multirow[b]{2}{*}{$\begin{array}{l}\text { Percent } \\
\text { Difference }\end{array}$} \\
\hline & & & $\begin{array}{l}\text { Stoch. and } \\
\text { Thermal* }\end{array}$ & $\begin{array}{l}\text { Only } \\
\text { Thermal } \\
\end{array}$ & \\
\hline \multirow{6}{*}{$\begin{array}{l}\text { Timing } \\
\text { (h) }\end{array}$} & \multicolumn{2}{|c|}{ First fuel failure (clad. gap release) } & 12.3 & 12.3 & $-0.2 \%$ \\
\hline & \multicolumn{2}{|c|}{$0.5 \mathrm{~kg}$ of $\mathrm{H}_{2}$ is generated } & 12.3 & 12.2 & $-0.7 \%$ \\
\hline & \multicolumn{2}{|c|}{$100 \mathrm{~kg}$ of $\mathrm{H}_{2}$ is generated } & 12.6 & 13.0 & $3.4 \%$ \\
\hline & \multicolumn{2}{|l|}{ Lower head failure } & 21.6 & 21.2 & $-1.8 \%$ \\
\hline & \multicolumn{2}{|c|}{ First deflagration in building } & 21.8 & 21.5 & $-1.7 \%$ \\
\hline & \multicolumn{2}{|c|}{$0.5 \mathrm{~kg}$ of noble gas release to envir. } & 21.8 & 16.6 & $-23.8 \%$ \\
\hline \multirow{7}{*}{$\begin{array}{l}\text { Total } \\
(\mathrm{kg})\end{array}$} & \multicolumn{2}{|c|}{$\mathrm{H}_{2}$ gas generated by end of sim. } & 1482 & 2729 & $84.2 \%$ \\
\hline & \multicolumn{2}{|c|}{ CO gas generated by end of sim. } & 21121 & 24558 & $16.3 \%$ \\
\hline & \multirow{5}{*}{$\begin{array}{l}\text { Radionuclide mass } \\
\text { released to } \\
\text { environment by } \\
\text { end of simulation* }\end{array}$} & Class $1(\mathrm{Xe})$ & $4.27 \mathrm{E}+02$ & $4.28 \mathrm{E}+02$ & $0.1 \%$ \\
\hline & & Class $2(\mathrm{Cs})$ & $3.17 \mathrm{E}+00$ & $2.88 \mathrm{E}+00$ & $-9.4 \%$ \\
\hline & & Class $3(\mathrm{Ba})$ & $1.12 \mathrm{E}+01$ & $2.57 \mathrm{E}+01$ & $129.1 \%$ \\
\hline & & Class 4 (I) & $9.70 \mathrm{E}-03$ & $5.48 \mathrm{E}-04$ & $-94.3 \%$ \\
\hline & & Class $16(\mathrm{CsI})$ & $2.34 \mathrm{E}+00$ & $1.59 \mathrm{E}+00$ & $-32.1 \%$ \\
\hline
\end{tabular}

*Base case; MELCOR 1.8.6, Eight wet well control volumes, modified safety relief valve (SRV) logic, and stochastic SRV failure.

*See MELCOR Computer Code Manuals, Version 1.8.5, NUREG/CR-6119, Rev. 2, Sandia National Laboratories, Albuquerque, N.M., for a summary of the constituents of the radionuclide classes.

Table 7. Safety relief valve failure modes result summary (2)

\begin{tabular}{|c|c|c|c|c|c|}
\hline \multirow{2}{*}{ Figure of Merit } & \multirow{2}{*}{\multicolumn{2}{|c|}{ Figure of Merit }} & \multicolumn{2}{|c|}{ SRV Failure Mode } & \multirow[b]{2}{*}{$\begin{array}{l}\text { Percent } \\
\text { Difference }\end{array}$} \\
\hline & & & $\begin{array}{l}\text { Stoch. and } \\
\text { Thermal* }\end{array}$ & $\begin{array}{l}\text { No } \\
\text { Failure }\end{array}$ & \\
\hline \multirow{6}{*}{$\begin{array}{l}\text { Timing } \\
\text { (h) }\end{array}$} & \multicolumn{2}{|c|}{ First fuel failure (clad. gap release) } & 12.3 & 12.3 & $-0.2 \%$ \\
\hline & \multicolumn{2}{|c|}{$0.5 \mathrm{~kg}$ of $\mathrm{H}_{2}$ is generated } & 12.3 & 12.2 & $-0.7 \%$ \\
\hline & \multicolumn{2}{|c|}{$100 \mathrm{~kg}$ of $\mathrm{H}_{2}$ is generated } & 12.6 & 13.0 & $3.4 \%$ \\
\hline & \multicolumn{2}{|c|}{ Lower head failure } & 21.6 & 23.1 & $7.2 \%$ \\
\hline & \multicolumn{2}{|c|}{ First deflagration in building } & 21.8 & 30.3 & $38.7 \%$ \\
\hline & \multicolumn{2}{|c|}{$0.5 \mathrm{~kg}$ of noble gas release to envir. } & 21.8 & 21.5 & $-1.4 \%$ \\
\hline \multirow{7}{*}{$\begin{array}{l}\text { Total } \\
(\mathrm{kg})\end{array}$} & & 1482 & 2463 & $66.2 \%$ \\
\hline & \multicolumn{2}{|c|}{ CO gas generated by end of sim. } & 21121 & 15969 & $-24.4 \%$ \\
\hline & \multirow{5}{*}{$\begin{array}{l}\text { Radionuclide mass } \\
\text { released to } \\
\text { environment by } \\
\text { end of } \\
\text { simulation** }\end{array}$} & Class $1(\mathrm{Xe})$ & $4.27 \mathrm{E}+02$ & $4.26 \mathrm{E}+02$ & $-0.3 \%$ \\
\hline & & Class $2(\mathrm{Cs})$ & $3.17 \mathrm{E}+00$ & $1.30 \mathrm{E}+00$ & $-58.9 \%$ \\
\hline & & Class $3(\mathrm{Ba})$ & $1.12 \mathrm{E}+01$ & $1.95 \mathrm{E}+01$ & $73.7 \%$ \\
\hline & & Class 4 (I) & $9.70 \mathrm{E}-03$ & $1.09 \mathrm{E}-03$ & $-88.8 \%$ \\
\hline & & Class $16(\mathrm{CsI})$ & $2.34 \mathrm{E}+00$ & $2.43 \mathrm{E}+00$ & $3.9 \%$ \\
\hline
\end{tabular}

*Base case; MELCOR 1.8.6, Eight wet well control volumes, modified safety relief valve (SRV) logic, and stochastic SRV failure .

**See MELCOR Computer Code Manuals, Version 1.8.5, NUREG/CR-6119, Rev. 2, Sandia National Laboratories, Albuquerque, N.M., for a summary of the constituents of the radionuclide classes. 
Table 8. Additional safety relief valve failure modes results

\begin{tabular}{|l|l|r|r|r|}
\hline \multirow{2}{*}{\multicolumn{2}{|c|}{ Figure of Merit }} & \multicolumn{2}{c|}{ SRV Failure Mode } \\
\cline { 3 - 5 } \multicolumn{2}{|c|}{} & $\begin{array}{l}\text { Stoch. and } \\
\text { Thermal }\end{array}$ & $\begin{array}{l}\text { Only } \\
\text { Thermal }\end{array}$ & \multicolumn{1}{l|}{$\begin{array}{l}\text { No } \\
\text { Failure }\end{array}$} \\
\hline Timing (h) & Timing of SRV Failure & 11.7 & 15.3 & NA \\
\hline Number & Total SRV-1 Actuations & 270 & 422 & 803 \\
\hline \multirow{2}{*}{ Mode } & SRV Failure Mode & Stoch. & Thermal & NA \\
\cline { 2 - 5 } & RPV Failure Mode & Penetration & Penetration & Yielding \\
\hline Temp. (K) & Melt Pour Temperature & 2320 & 2360 & 2000 \\
\hline
\end{tabular}

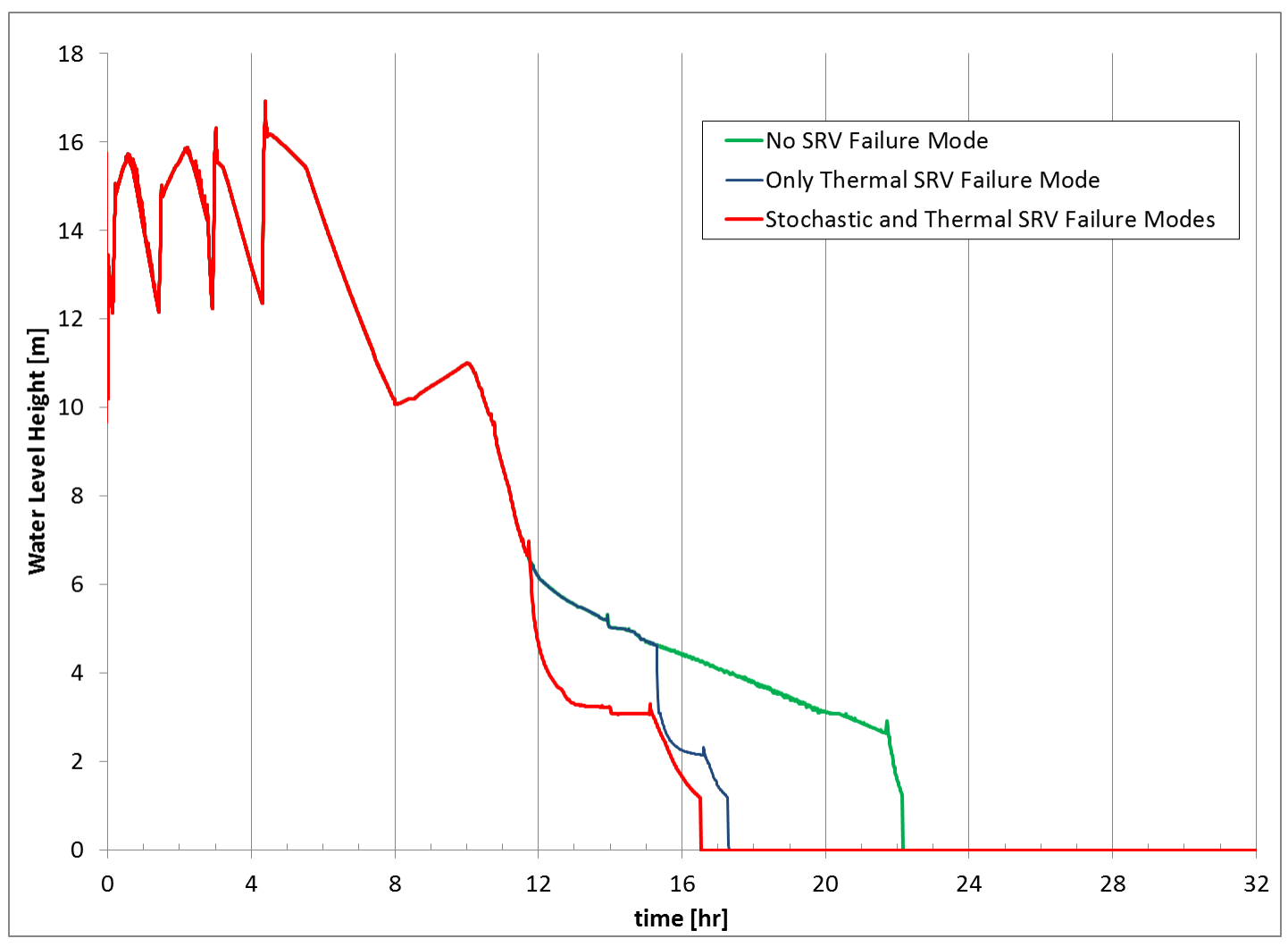

Fig. 17. Reactor water level response, safety relief valve failure mode modeling. 


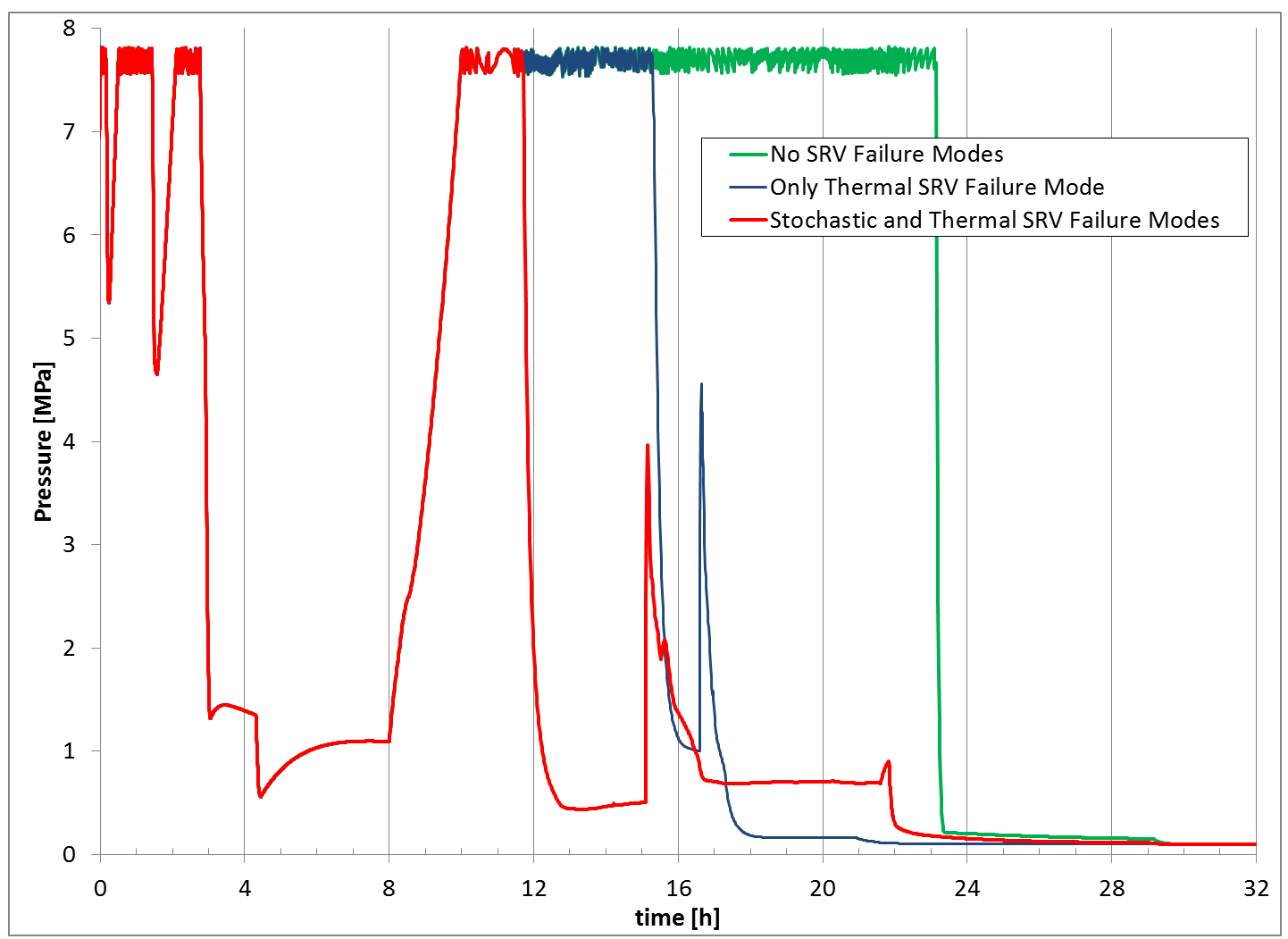

Fig. 18. Reactor pressure response, safety relief valve failure mode modeling.

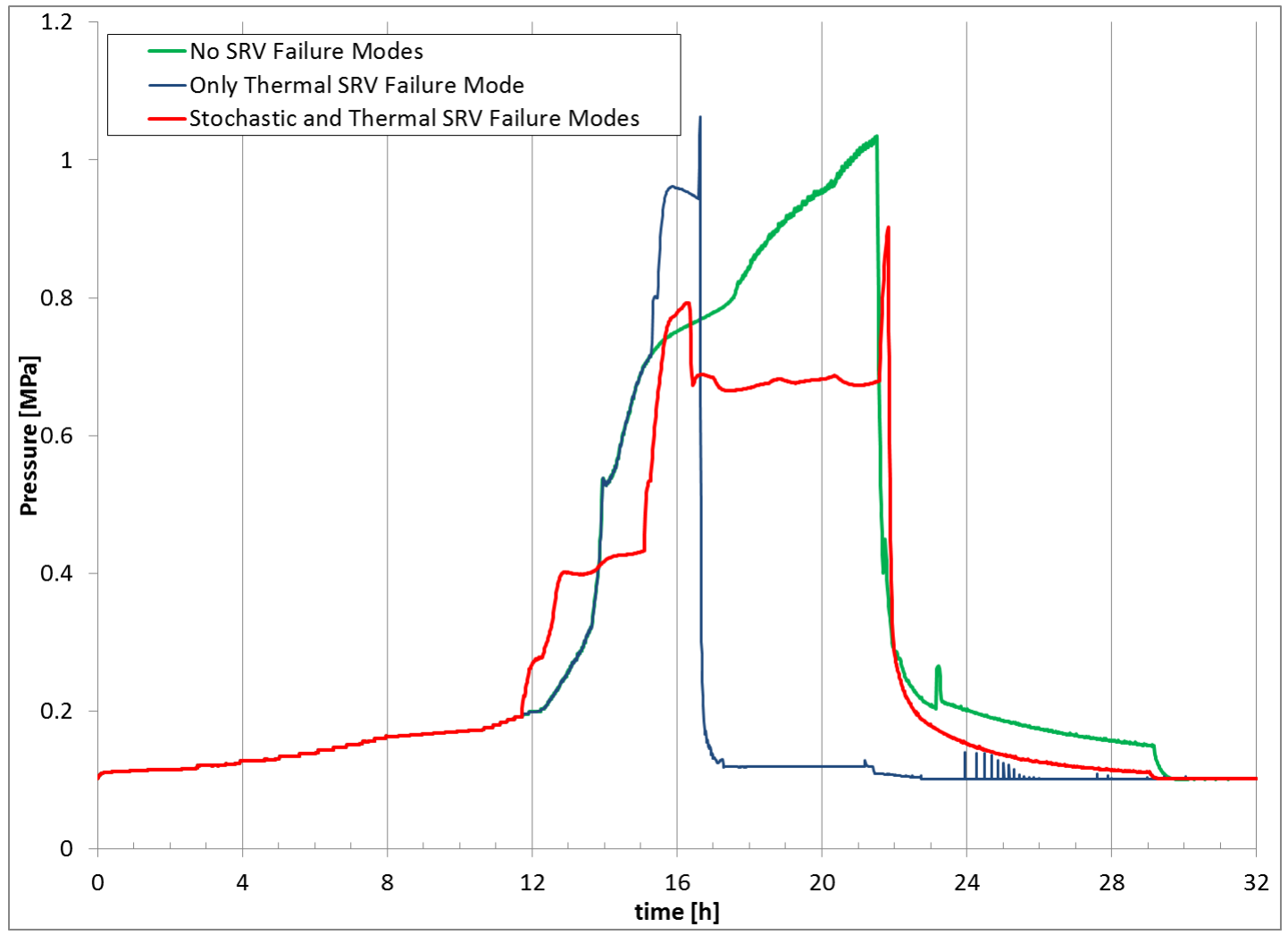

Fig. 19. Containment pressure response, safety relief valve failure mode modeling. 


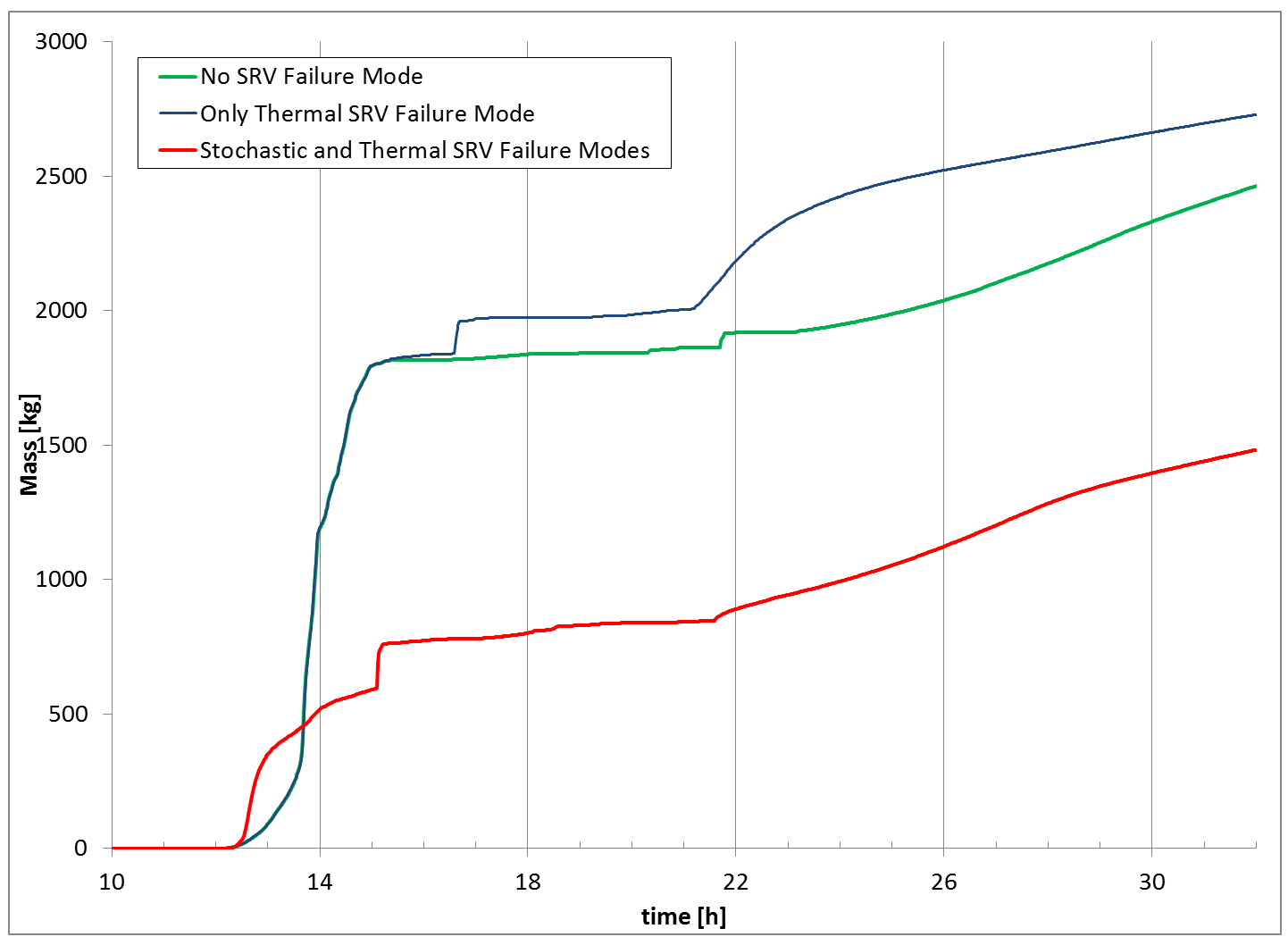

Fig. 20. Hydrogen generation response, safety relief valve failure mode modeling.

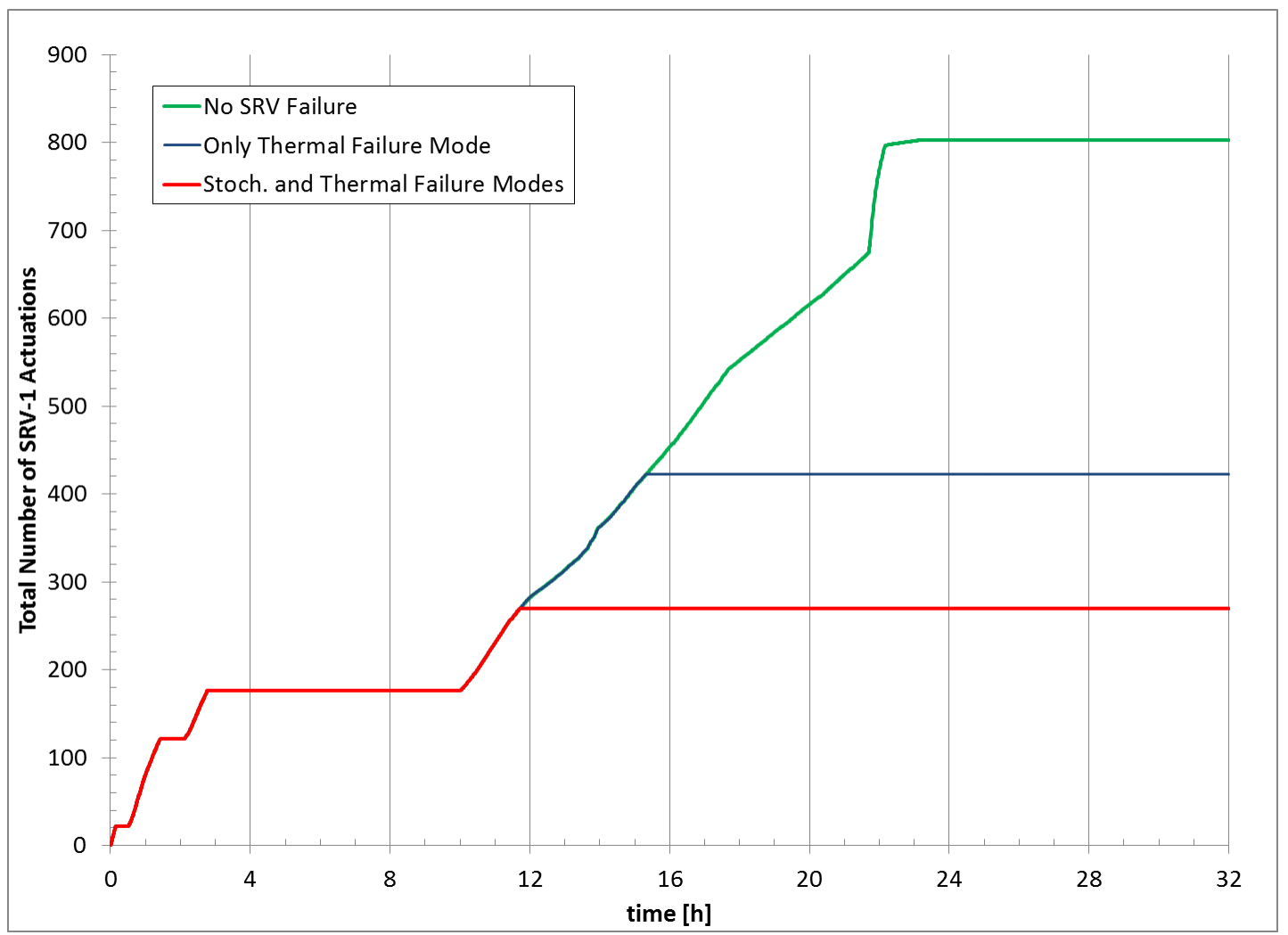

Fig. 21. Number of safety relief valve (SRV) actuations, SRV failure mode modeling. 



\section{SUMMARY OF FINDINGS}

Four upgrades to the Peach Bottom MELCOR model were performed. The update from MELCOR 1.8.5 to MELCOR 1.8.6 resulted in a different predicted lower head failure mode and therefore lower head failure timing. Increasing the wet well discretization resulted in higher pressures and failure of containment earlier in the simulation. The modification of the SRV actuation pressure logic resulted in later failure of the lower head. This, in turn, affected the melt release conditions (temperature), the melt spread area, and ultimately the amount of carbon monoxide generated from molten core-concrete interaction. The addition of the stochastic SRV failure mode resulted in earlier predicted failure of the SRV, depressurizing the RPV, and largely affecting the subsequent predicted accident progression timing. In general, the SRV failure modes were found to have a large impact on the accident progression timing. All four model upgrades were found to have important impacts on the accident timing, sequence, and releases. Due to the impact of these upgrades, it is recommended these modeling upgrades be further investigated and refined in the future. 



\section{REFERENCES}

1. I. K. Madni, "MELCOR Simulation of Long-Term Station Blackout at Peach Bottom," Water Reactor Safety Research Information Meeting, Gaithersburg, Md., October 22-24, 1990.

2. J. J. Carbajo, Severe Accident Source Term Characteristics for Selected Peach Bottom Sequences Predicted by the MELCOR Code, NUREG/CR-5942, Oak Ridge National Laboratory, Oak Ridge, Tenn., July 1993.

3. J. J. Carbajo, MELCOR DBA LOCA Calculations, ORNL/NRC/LTR-97-21, Oak Ridge National Laboratory, Oak Ridge, Tenn., January 1999.

4. M. T. Leonard et al., Office of Nuclear Reactor Research, Dycoda, LLC, A General Purpose MELCOR Model of a BWR/4 Mark I Nuclear Power Plant, Sandia National Laboratories, Albuquerque, N.M., draft report, November 2004.

5. R. L. Sanders, Analysis of a MELCOR Input Deck for the Peach Bottom Atomic Power Station, ORNL/NRC/LTR-03/03, Oak Ridge National Laboratory, Oak Ridge, Tenn., February 2003.

6. M. W. Francis and J. B. Garvey, "Long-Term Station Blackout MELCOR Model for a BWR-4 Mark I Containment," M. S. Thesis, Nuclear Engineering Department, The University of Tennessee, Knoxville, May 2006.

7. M. W. Francis, "Long-Term Station Blackout Sequence and Mitigation MELCOR Model," M.S. Thesis, The University of Tennessee, Knoxville, May 2006.

8. MELCOR Computer Code Manuals, Version 1.8.5, NUREG/CR-6119, Rev. 2, Sandia National Laboratories, Albuquerque, N.M., October 2000.

9. MELCOR Computer Code Manuals, Version 1.8.6, NUREG/CR-6119, Rev. 3, Sandia National Laboratories, Albuquerque, N.M., September 2005.

10. MELCOR Computer Code Manuals, Version 2.1, NUREG/CR-6119, Rev. 4, Sandia National Laboratories, Albuquerque, N.M., September 2008, Draft.

11. J. E. Cash, "Input Deck Conversion,” Seventh MELCOR User’s Workshop, Albuquerque, N.M., September 26-30, 2005.

12. State-of-the-Art Reactor Consequence Analyses Project; Volume 1: Peach Bottom Integrated Analysis, NUREG/CR-7110, Vol. 1, Sandia National Laboratories, Albuquerque, N.M., January 2012.

13. D. H. COOK, Pressure Suppression Pool Thermal Mixing, NUREG/CR-3471, ORNL/TM-8906, Oak Ridge National Laboratory, Oak Ridge, Tenn., October 1984.

14. K. Robb et al., "1F3 Modeling with MELCOR 1.8.5," Fukushima Daiichi accident response meeting, sponsored by DOE-NE, Washington, D.C., January 25, 2012.

15. R. O. Gauntt et al., Fukushima Daiichi Accident Study, SAND2012-6173, Sandia National Laboratories, Albuquerque, N.M., July 2012. 
16. Severe Accident Risks: An Assessment for Five US Nuclear Power Plants, NUREG-1150, US Nuclear Regulatory Commission, Washington, D.C., 1990.

17. Report of Japanese Government to the IAEA Ministerial Conference on Nuclear Safety-The Accident at TEPCO's Fukushima Nuclear Power Stations, Nuclear Emergency Response Headquarters, Government of Japan, June 2011.

18. K. R. Robb, M. T. Farmer, and M. W. Francis, Ex-Vessel Core Melt Modeling Comparison between MELTSPREAD-CORQUENCH and MELCOR 2.1, ORNL/TM-2014/1, Oak Ridge National Laboratory, Oak Ridge, Tenn., March 2014.

19. L. L. Humphries, "MELCOR Code Development Status, Code Assessment, and QA," Proc. of MELCOR Code Assessment Program (MCAP) Meeting, Bethesda, Md., September 22-23, 2011. 


\section{APPENDIX A. INPUT USED IN MELCOR CONVERTER UTILITY}

The following tables summarize the values used in the MELCOR 1.8.5 to MELCOR 1.8.6 converter utility. The values in bold are numbers supplied to the converter utility.

Table A-1. Bottom head geometry input

\begin{tabular}{ll}
\hline \multicolumn{1}{c}{ Parameter } & Value Used \\
\hline RCOR & $\mathbf{2 . 5 8 4 4 5}$ \\
RVESS & $\mathbf{3 . 1 8 7 7}$ \\
RVLH & $\mathbf{3 . 4 3 7 7}$ \\
HLST & $\mathbf{3 . 0 8 6 1}$ \\
HCSP & $\mathbf{5 . 1 1 5 6}$ \\
Origin & 2.736103 \\
DZLH & $\mathbf{0 . 2 1 7 6}$ \\
DZRV & $\mathbf{0 . 1 6 6 7}$ \\
ILHTRN & $\mathbf{0}$ \\
ILHTYP & $\mathbf{0}$ \\
\hline
\end{tabular}

Table A-2. Ring radius input

\begin{tabular}{cl}
\hline Ring & \multicolumn{1}{c}{ Radius } \\
\hline 1 & $\mathbf{1 . 1 0 3 2 7 6}$ \\
2 & $\mathbf{1 . 5 6 0 2 6 7}$ \\
3 & $\mathbf{1 . 8 9 5 8 3 6}$ \\
4 & $\mathbf{2 . 1 8 0 3 5 7}$ \\
5 & $\mathbf{2 . 5 8 4 4 5}$ \\
6 & $\mathbf{3 . 1 8 7 7}$ \\
\hline
\end{tabular}

Table A-3. Elevation discretization input

\begin{tabular}{cll}
\hline Elevation & \multicolumn{1}{c}{$\mathbf{Z}$} & \multicolumn{1}{c}{$\mathbf{d Z}$} \\
\hline 1 & $\mathbf{0}$ & 1.170896 \\
2 & $\mathbf{1 . 1 7 0 8 9 6}$ & 1.915204 \\
3 & $\mathbf{3 . 0 8 6 1}$ & 2.0295 \\
4 & 5.1156 & 0.0844 \\
5 & 5.2 & 0.0166 \\
6 & 5.2166 & 0.0698 \\
7 & 5.2864 & 0.2079 \\
8 & 5.4943 & 0.635 \\
9 & 6.1293 & 0.635 \\
10 & 6.7643 & 0.635 \\
11 & 7.3993 & 0.635 \\
12 & 8.0343 & 0.635 \\
13 & 8.6693 & 0.635 \\
14 & 9.3043 & 0.3627 \\
\hline
\end{tabular}


Table A-4. External control volumes and temperature input

\begin{tabular}{cllcc}
\hline Segment & \multicolumn{1}{c}{ Radius } & Elevation & Temperature & ICVCAV \\
\hline 1 & 1.103276 & 0.181849 & $\mathbf{5 6 1 . 0}$ & $\mathbf{1 0 5}$ \\
2 & 1.560267 & 0.374475 & $\mathbf{5 6 1 . 0}$ & $\mathbf{1 0 5}$ \\
3 & 1.895836 & 0.570021 & $\mathbf{5 6 1 . 0}$ & $\mathbf{1 0 5}$ \\
4 & 2.180357 & 0.779915 & $\mathbf{5 6 1 . 0}$ & $\mathbf{1 0 5}$ \\
5 & 2.58445 & 1.170896 & $\mathbf{5 6 1 . 0}$ & $\mathbf{1 0 5}$ \\
6 & 3.1877 & 2.150707 & $\mathbf{5 6 1 . 0}$ & $\mathbf{1 0 5}$ \\
7 & 3.1877 & 3.0861 & $\mathbf{5 6 1 . 0}$ & $\mathbf{1 0 5}$ \\
\hline
\end{tabular}




\section{APPENDIX B. SUPPRESSION POOL DISCRETIZATION}

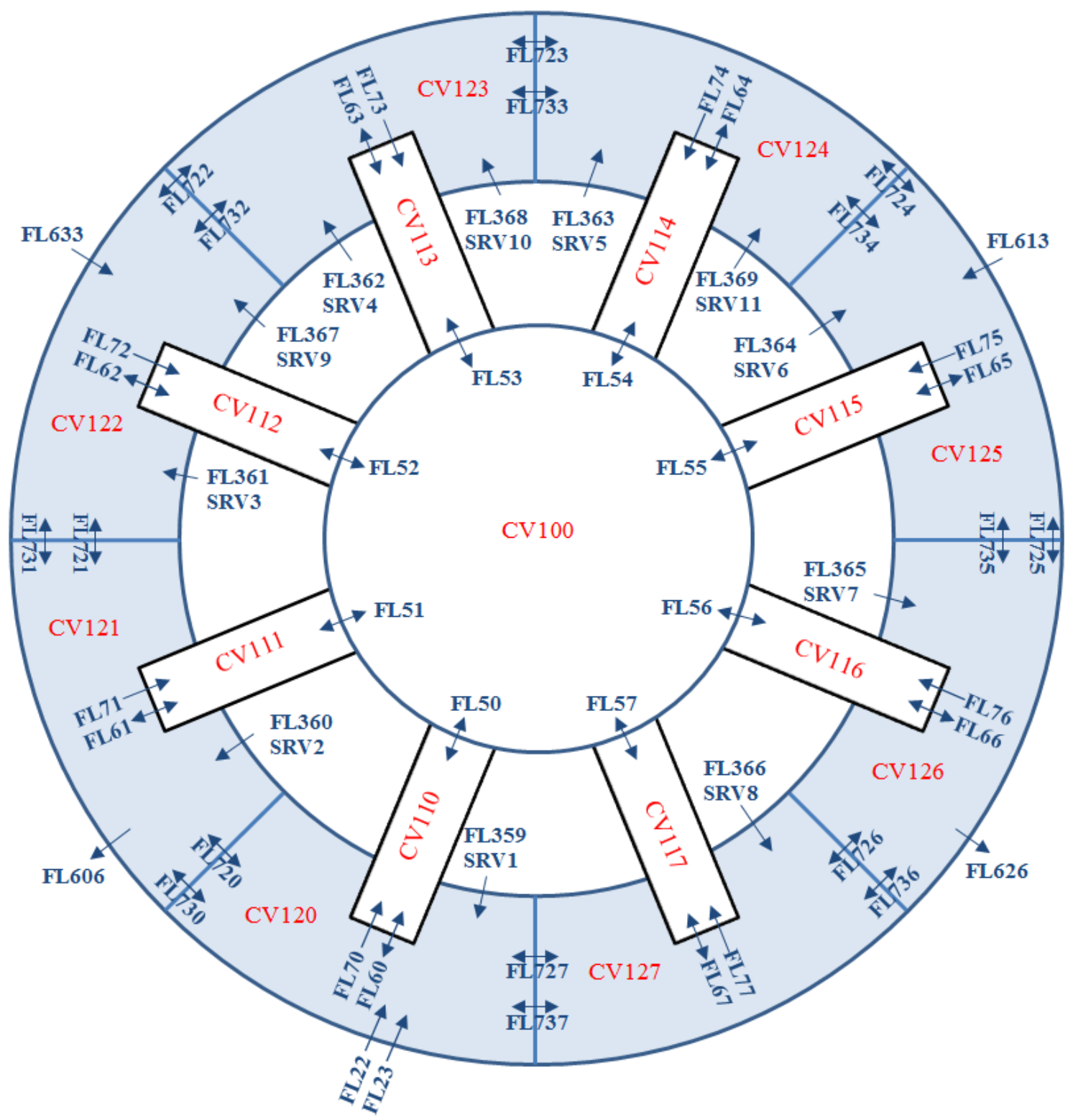

Fig. B-1. Suppression pool discretization.

\begin{tabular}{|c|c|}
\hline FL series & Description \\
\hline $73 x$ & $\overline{\text { SC-SC section upper flow }}$ \\
\hline $72 \mathrm{x}$ & SC-SC section lower flow \\
\hline $07 x$ & Vent vacuum breaker \\
\hline $06 x$ & Vent/downcomer outlet \\
\hline $05 x$ & Dry well-Vent flow \\
\hline $359-369$ & SRV steam flow \\
\hline
\end{tabular}

*SC: suppression chamber

$\begin{array}{ll}\underline{\mathbf{F L}} & \text { Description } \\ 613 & \text { RCIC steam outlet } \\ 606 & \text { HPCI steam outlet } \\ 626 & \text { RCIC SC suction } \\ 22,23 & \text { HPCI SC suction } \\ & \text { Pool to room vacuum breaker }\end{array}$

FL $\quad$ Description

$613 \quad$ RCIC steam outlet

633 HPCI steam outlet

$626 \quad$ HPCI SC suction 
